\title{
The role of port authorities in the development of LNG bunkering facilities in North European ports
}

\author{
Siyuan Wang • Theo Notteboom
}

Received: 22 August 2014 / Accepted: 16 December 2014 / Published online: 14 January 2015

(C) World Maritime University 2015

\begin{abstract}
Liquefied natural gas (LNG) serves as an attractive fuel for ships to meet the upcoming stringent environmental regulations enacted by IMO, particularly at the level of emission control areas (ECA). The use of LNG promises a good environmental performance and a foreseeable economic viability. However, a general absence of bunkering infrastructure in seaports is a significant barrier currently preventing the breakthrough of the use of LNG as a ship fuel. Against this backdrop, we observe that public port authorities are playing a proactive role in facilitating the use of LNG as a marine fuel. The purpose of this paper was to analyze the role of port authorities in the development of LNG bunkering facilities and to investigate why and how port authorities promote this new application. A multiple-case study approach is adopted to examine the performance of eight North European port authorities in their LNG bunkering projects. The paper provides a deeper understanding of the current port practices in developing LNG bunkering facilities in North Europe and identifies the important role of the evolving port function beyond the tradition model in promoting innovations. The paper also proposes a set of port implementation policies on the facilitation and promotion of the use of LNG as a ship fuel.
\end{abstract}

Keywords Port authorities $\cdot$ LNG $\cdot$ Bunkering facilities $\cdot$ Multiple-case study $\cdot$ North Europe

\footnotetext{
S. Wang $\cdot$ T. Notteboom $(\bowtie)$

Institute of Transport and Maritime Management Antwerp (ITMMA), University of Antwerp, Kipdorp 59, 2000 Antwerp, Belgium

e-mail: theo.notteboom@gmail.com

S. Wang

e-mail: siyuan.wang@uantwerpen.be

T. Notteboom

Transportation Management College, Dalian Maritime University, 1 Linghai Road, Dalian 116026

Liaoning, China
} 


\section{Introduction}

Shipping activities and associated port operations create negative impacts on the environment especially in port areas which are usually situated within or in close proximity to urban areas. Examples of these impacts are air emissions (mainly $\mathrm{CO}_{2}$, $\mathrm{NO}_{\mathrm{x}}, \mathrm{SO}_{\mathrm{x}}$, and particulate matter (PM)) from the ship's main and auxiliary engines, noise caused by cargo-loading facilities, and dust from the handling of substances such as grain, sand, and coal. At an international level, IMO has set stricter regulations under MARPOL Annex VI to reduce $\mathrm{SO}_{\mathrm{x}}, \mathrm{NO}_{\mathrm{x}}$ and PM emissions from sea-going vessels, particularly in emission control areas (ECA). Facing the upcoming stringent environmental standards, ship operators have to look for innovative compliant solutions which could promise a good environmental performance as well as a foreseeable economic viability. Using low sulfur fuels, operating scrubbers or switching to liquefied natural gas (LNG) are the most feasible options at present. LNG is a strong option from an economic and environmental performance standpoint. LNG is a natural gas which becomes liquid at a temperature of $-160{ }^{\circ} \mathrm{C}$. Liquefied gas occupies a volume corresponding to $1 / 600$ of the product in the gaseous state, which makes it space efficient to be stored as a bunker onboard ships. Compared to conventional ship fuels, LNG as a clean energy can reduce $\mathrm{NO}_{\mathrm{x}}$ by up to $85-90 \%, \mathrm{SO}_{\mathrm{x}}$ and $\mathrm{PM}$ by close to $100 \%$, and $\mathrm{CO}_{2}$ by $15-20 \%$ (Pitt 2010). However, as a new emerging technology, the use of LNG as a ship fuel faces several key challenges which might prevent the breakthrough of this application. According to Wang and Notteboom (2013), the current lack of LNG bunkering infrastructure and operational standards together with the intensive capital cost and the associated investment risks deter shipowners, bunkering operators, and facility investors to step forward and adopt this clean and innovative solution. The "chicken-and-egg" problem represents the current market dilemma where bunker suppliers and shipowners both follow a "wait and see" approach expecting the other party to take the initiative.

The role of government and public authorities in initiating and enhancing the largescale adoption of new technologies, and thus breaking the market-based chicken-andegg dilemma, is a common theme in scientific research. For example, the academic literature includes studies on the effects of government programs for renewable energy (Loiter and Norberg-Bohm 1999; Åstrand and Neij 2006) and for clean energy vehicles, like electric cars, methanol-fueled vehicles, and compressed natural gas (CNG) vehicles (Cowan and Hulten 1996; Chan and Chau 1997; Åhman 2006). Along these lines, some public authorities, like national governments or supranational bodies (e.g., EU), have started to promote the use of LNG as a ship fuel by establishing harmonized bunkering regulations/standards and financial support schemes. Moreover, we observe that public port authorities have found their responsibility to develop LNG bunkering facilities in their respective port areas. We will demonstrate that they are currently adopting a proactive role in facilitating this new application in the shipping industry.

The purpose of this paper was to explore the role of port authorities in the development of LNG bunkering facilities and to investigate why and how port authorities play a proactive role in promoting this new application. We adopt a multiple-case study approach to examine the performance and involvement of eight North European public port authorities in their LNG bunkering projects. These ports, all located in the 
North Sea or Baltic Sea ECA, share a great ambition for the use of this clean fuel option due to a big pressure of the forthcoming strict ECA emission standards. The case study data for these ports are collected from two sources. The first group includes port documents such as annual reports, business plan, and archival records. The second source relies on structured interviews with senior port representatives who are in charge of the respective LNG bunkering projects in these eight ports. The paper not only provides a deeper understanding of the current development status of LNG bunkering in these eight European ports but also emphasizes that a proactive role beyond the traditional landlord model which port authorities intend to play could effectively facilitate and promote innovative technologies, like LNG. In addition, the paper also proposes a set of port implementation policies on the facilitation and promotion of the maritime use of LNG.

The paper is structured as follows: section 2 firstly presents the theoretical foundation which leads port authorities to play a proactive role in promoting the maritime use of LNG, and then identifies the research questions and outlines research design which follows a rigorous methodological path for conducting a multiple-case study. Section 3 presents an extensive cross-case study to investigate how eight North European port authorities are presently developing LNG bunkering infrastructure and also conducts a discussion on the role of the evolving port function beyond the traditional model in promoting innovations. Section 4 draws conclusions and identifies the implications for managerial practice and the contribution to scholarly knowledge and finally discusses the research limitations.

\section{Methodology}

2.1 Theoretical foundation on the role of port authorities in the development of LNG as a ship fuel

Why should port authorities play a proactive role in developing green innovative technologies? In this section, we present and discuss three theory-based reasons. First, the innovative technology enables ports to achieve "green and sustainable" objectives. Secondly, port authorities play an important role in their respective regional innovation system (RIS) in view of establishing social collaboration and knowledge creation and therefore to promote innovation. Finally, port authorities typically seek for meaningful extensions of their function beyond the traditional model. Promoting innovations in the port community adds to the facilitating and coordinating role of port authorities. The three theoretical bases not only provide an in-depth explanation on the concerned question but also suggest a practice guideline on how port authorities should play a proactive role in the development of LNG as a marine fuel.

\subsubsection{Green and sustainable port strategy}

Over the last decades, port authorities, as public managing bodies of the port, have been subject to port reform through privatization and corporatization schemes (Notteboom and Winkelmans 2002; Goss 1990; Baird 2000). These port reform processes typically serve as an answer to the call for better port performance and competitiveness, e.g., 
maximizing land use and infrastructure, increasing cargo throughput and value-added creation, reducing operation cost, and strengthening hinterland connections (Kim et al. 2013). However, a new stream of port strategies has emerged aiming at enhancing the relationship with the local community by focusing on social and environmental aspects. Corporate social responsibility (CSR) in ports has drawn a lot of attention in recent years. CSR has become an integral part of port strategy definition (Dooms and Verbeke 2007; Adams et al. 2010). In addition, pursuing a sustainable development incorporating economic, social, and environmental concerns has become a key theme of contemporary port strategy (Cheon and Deakin 2010; Adams et al. 2010; Lam and Van de Voorde 2012). ESPO (2013) defined "port sustainability" as "business strategies and activities that meet the current and future needs of the port and its stakeholders, while protecting and sustaining human and natural resources." Ports are thus challenged to simultaneously pursue economic prosperity, environmental quality, and social responsibility.

The environmental impact of port operations has attracted a rising concern due to the associated negative externalities for the local community. The motives for and drivers of environmental initiatives by ports emanate not only from the pressures of regulatory compliance and societal requirements but also from the objective of more efficient port operations and the creation of competitive advantages (Adams et al. 2010). The concept of "Green Port" emerged in line with an increasing awareness that a good environmental performance is a necessary requirement to maintain good relations with local communities as well as a source of competitive advantage (Denktas-Sakar and KaratasCetin 2012; Wiegmans and Geerlings 2010). According to Kim et al. (2013), a green and sustainable strategy improves port competitiveness. Moreover, any "green" strategy can be considered as an integral part of "agile" port strategies (Mangan et al. 2008; Marlow and Paixão-Casaca 2003) which requires the ability of the port to quickly adapt to and influence upcoming regulations and to respond rapidly to customer environmental demands. Therefore, the pursuit of a green and sustainable port strategy is seen as one of main ways to obtain port competitiveness, while innovative technology could provide an efficient solution to deal with some of the environmental issues faced by ports. A strong port strategy toward the promotion of innovation can contribute significantly to achieve this goal (Acciaro et al. 2013).

\subsubsection{The role of port authorities in regional innovation system (RIS)}

The concept of regional innovation system (RIS) was introduced in evolutionary economics. A RIS is a regional system "in which firms and other organizations are systematically engaged in interactive learning through an institutional milieu characterized by embeddedness" (Cooke et al. 1998) or "a system of innovative networks and institutions located which a certain geographic area, with regular and strong internal interacting that promotes the innovativeness of the region's companies" (Kostiainen 2002). Doloreux (2002) defines firms (economic agents/commercial organizations), institutions (governments, public authorities, etc.), knowledge infrastructure (e.g., science/technology parks, R\&D institutions, etc.) and innovative policies as four main elements comprising a regional innovation system. Interactive and collective learning among various public and private actors is the key theme of RIS, since innovation results from a process of interactive learning (Harmaakorpi 2006). It is noted that public 
authorities are crucial players who shape the environment in a way that both stimulates technical innovation and provides the normative structure (laws, rules, or standards) that promotes the stable social interactions necessary for the performance of a RIS (Doloreux 2002). The involvement of public sectors in the process of innovation could be called for in all development phases (e.g., R\&D, field tests, demonstration, market introduction, and diffusion), including the funding of $R \& D$, financial support for gaining experience and increasing the scale of production, dissemination of information, building of industrial networks, and creating standards (Åhman 2006; Freeman 1994). Innovative policy formulated by governments or other public authorities plays a crucial role in improving interactive learning and knowledge share between firms, institutions, and knowledge infrastructure in RIS (Hassink 1993).

The contribution of a port as public infrastructure to regional economic development is well recognized due to its ability to facilitate trade and maritime economic activities, generate employment, and attract investment (De Langen 2004; Bryan et al. 2006). In addition, port regionalization processes (Notteboom and Rodrigue 2005) have brought port development to a higher geographical scale, thereby increasing the functional role of the broader port area in regional development. The port authority, mostly a public managing body of the port, should be considered as a key player in its regional innovation system and in exploiting regional business opportunities through the development of an innovation network (Cahoon et al. 2013). To be a successful network leader in RIS, the port authority should be a proactive coordinating or facilitating player by establishing industrial networks, enhancing social collaboration, and improving interactive learning effects between various industry players (Chen et al. 2010).

\subsubsection{The evolving function of port authority}

Public port authorities traditionally can assume three typical functions, that of landlord, regulator, and operator (Baird 1995; Baltazar and Brooks 2001; De Monie 2004; Verhoeven 2010). The landlord and regulator function have become the two main functions corresponding to the general definition of the traditional "landlord port model." In this model, the operation function in terms of cargo handling has largely been transferred to private operators (Verhoeven 2010). The "landlord model," which has been adopted as the principal function of contemporary port authorities (Notteboom and Winkelmans 2001a, b; Dooms and Verbeke 2007), assumes a strong role of the port authority in the management, maintenance, and development of the port area, the provision of infrastructure and facilities, as well as the conception and implementation of policies and development strategies linked to the exploitation of the port area (Baird 2000; Baltazar and Brooks 2001; Van Hooydonk 2003).

Traditional "landlord" ports are confronted with an ever-changing socioeconomic environment where globalization and liberalization processes increased the power of private port actors (carriers, shippers, terminal operators, and logistics service providers). In this regard, some scholars propose a "renaissance" of the port authority (Notteboom and Winkelmans 2001b; Verhoeven 2010), i.e., the port authority should play a more proactive role beyond the traditional function in facilitating and coordinating stakeholders in logistics networks and creating core competencies in the highly competitive market by even adopting a more entrepreneurial role (Chlomoudis et al. 2003; Comtois and Slack 2003; Notteboom and Winkelmans 2002; Van Der Lugt and 
De Langen 2007). De Langen (2004, 2007) makes a plea for a new functional role of port authorities as "cluster managers" or "community managers" to solve collective action problems in and outside the port perimeters, such as hinterland bottlenecks, training and education, ICT, marketing and promotion, as well as innovation and internationalization (economic dimension) (De Langen and Chouly 2004; Van Der Horst and De Langen 2007). Chlomoudis et al. (2003) refer to the community manager role of the port authority: "the systemic coordinator that advances and maintains good relationships with all port stakeholders, thus creating a port culture of trust."

\subsection{Research questions and case study method}

The paper is mainly focused on two research questions: (1) why do port authorities play a proactive role in promoting and facilitating the use of LNG as a marine fuel? (2) How do port authorities encourage and facilitate the use of this new green technology?

According to Yin (2009), "the case study method is most likely to be appropriate for "why" and "how" research questions. The more these research questions seek to explain some present circumstances the more relevant becomes the case study method." We adopt the case study approach to examine current port developments with respect to the use of LNG as a marine fuel. Also, the paper applies a multiple-case design (also considered "comparative studies" by Eckstein (1975)) in order to show compelling evidence making the overall study more robust (Herriott and Firestone 1983).

As Yin (2009) proposes, a multiple-case study requires five research steps: (1) the careful and thoughtful posing of research questions, (2) a thorough literature review on relevant theories or propositions, (3) the definition and selection of cases which best relate to the research questions and theories/propositions, (4) the collection and analysis of data as per each case and the completion of individual case report, and finally, (5) the presentation of cross-case conclusions and policy implications. In order to structure a good multiple-case study and to collect, present, and analyze data fairly, we strictly follow the above methodological path and present an explicit and transparent research process. The detailed research steps are illustrated in Fig. 1.

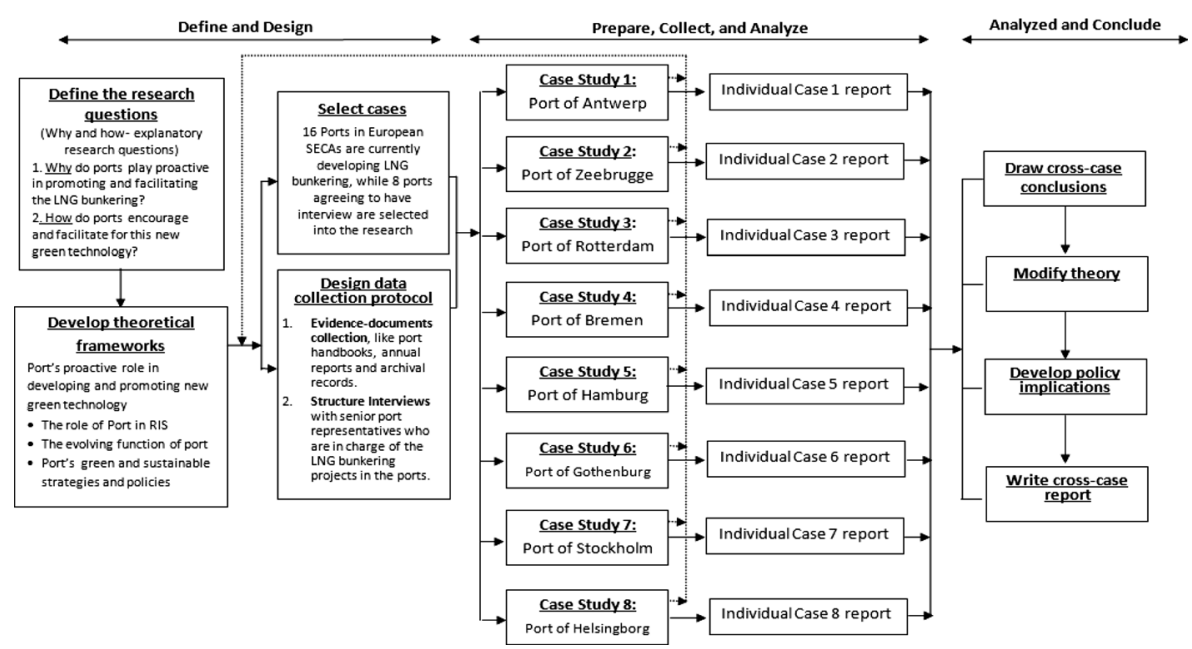

Fig. 1 Research design and methodology (multiple-case study). Source: own elaboration 
After having defined the research questions, the next step is to look for theories or propositions which could explain why port authorities are playing or should play a proactive role in developing LNG bunkering facilities. Through an extensive literature review, we have established a theoretical foundation to support the explanation and also provide a first insight on how port authorities should develop LNG bunkering facilities. This part has been discussed in detail in the above section.

The third step is to select the most related cases. We target for the ports located within the two European ECAs (the Baltic Sea and the North Sea ECAs) since they are confronted with a high pressure to comply with the stringent emission standards in 2015. After a thorough search, there are 16 ports ${ }^{1}$ identified in the area which are currently developing or planning to develop LNG bunkering facilities. In order to get more extensive evidence on the current level of involvement of port authorities in this new green application and to make the case study more robust, we sent interview invitations to the senior port representatives who are in charge of the respective LNG bunkering projects in these 16 ports. Eight port representatives from eight of the 16 ports agreed to participate in this study. Two ports declined the invitation to participate in the study since they had not yet developed solid plans for this new business by the time the invitations were sent (September, 2013). The rest of the five ports were finally not included in the study since we could not reach the corresponding representatives in these ports within the planned research schedule or the representatives stated they could not accept the invitation. Therefore, at last, there are eight ports selected into the case study: They are port of Antwerp (Belgium), port of Zeebrugge (Belgium), port of Rotterdam (The Netherlands), port of Bremen (Germany), port of Hamburg (Germany), port of Gothenburg (Sweden), port of Stockholm (Sweden), and port of Helsingborg (Sweden).

The fourth step includes the collection of data from the selected eight ports. The data mainly come from two sources: (1) documents like port handbooks, annual reports, and archival records and (2) information collected via structured interviews (either by faceto-face or telephone) ${ }^{2}$ with the senior port representatives (see the list of interviewees in Appendix 1) who are in charge of the LNG bunkering projects. The first source of data mainly helped in collecting general information on the port, such as its geographic features, port size, institutional structure, and port environmental strategies and policies. The second type of information was collected using a questionnaire composed of questions dealing with port authorities' actions in developing and facilitating the use of LNG as a ship fuel in line with each port function (i.e., landlord, "regulator," "operator," and "community manager") identified by the literature (discussed in section 2.1.3). Each question can be regarded as a unit of analysis, and the data was collected to create individual case reports for each port authority. After completing the eight individual port reports, an extensive cross-case study among the eight ports was conducted by analyzing and comparing the collected

\footnotetext{
${ }^{1}$ Port of Aarhus, Port of Amsterdam, Port of Antwerp, Port of Bremen, Port of Copenhagen Malmo, Port of Dover, Port of Dunkirk, Port of Gothenburg, Port of Hamburg, Port of Helsinki, Port of Helsingborg., Port of Le Havre, Port of Rotterdam, Port of Stockholm, Port of Tallinn, and Port of Zeebrugge.

${ }^{2}$ Port of Antwerp (face-to-face interview), Port of Zeebrugge (face-to-face interview), Port of Rotterdam (telephone interview), Port of Bremen (telephone interview), Port of Hamburg (face-to-face interview), Port of Gothenburg (telephone interview), Port of Stockholm (telephone interview), and Port of Helsingborg (telephone interview).
} 
data guided by each of unit of analysis. Section 4 presents the cross-case study in detail. The last step is to draw cross-case conclusions, to confront these conclusions with the first insights derived from theories in section 3 , and to develop port implementation policies on the development of LNG as a ship fuel.

2.3 The role of port authorities in the development of LNG as a ship fuel: a first assessment

Given the above theoretical context, the reasons for port authorities to play a proactive role in the promotion of the use of LNG as a ship fuel can be summarized as follows:

- To achieve green and sustainable objectives, port authorities not only need to take a responsibility to quickly adapt to the upcoming strict emission regulations but also need to respond to the environmental needs of the port users. The promotion of LNG as a ship fuel can nicely fit in this perspective.

- Port authorities can take up the role of coordinators or facilitators in the development of a regional innovation system in view of exploiting regional business opportunities by developing an innovation network. The development of LNG as an innovative way to deal with the environmental issue could add value to this role.

- Port authorities are more and more evolving from passive landlords and "regulators" to proactive community managers. The LNG discussion offers port authorities a window of opportunity to give an additional content to their emerging role as community managers.

The literature also provides some suggestions and practical guidance on how port authorities should promote and facilitate the use of LNG as a marine fuel. Considering the current challenges faced by this new application as identified by Wang and Notteboom (2013), Table 1 provides a first assessment of possible avenues ports can follow in view of enhancing and facilitating the maritime use of LNG (see Table 1):

- First of all, port authorities could assist in realizing some basic but essential steps to make LNG bunkering feasible, including investments in LNG bunkering infrastructure (e.g., land, jetty and maritime access, etc.), the assessment of the safety risks of the use of LNG in the port environment, and the development of a set of bunkering standards and guidelines.

- Second, to solve the current chicken-and-egg market dilemma, port authorities could take initiatives to establish social collaboration and improve interactive learning with other stakeholders, such as bunkering operators, shipowners, and asset investors, to develop a financially viable business plan for building an LNG bunkering supply network.

- Third, port authorities could develop a favorable innovation policy or tool to promote the maritime use of LNG. For instance, they could launch a pilot project to gain first experience, establish financial support schemes, and/or facilitate market introduction and knowledge diffusion. 


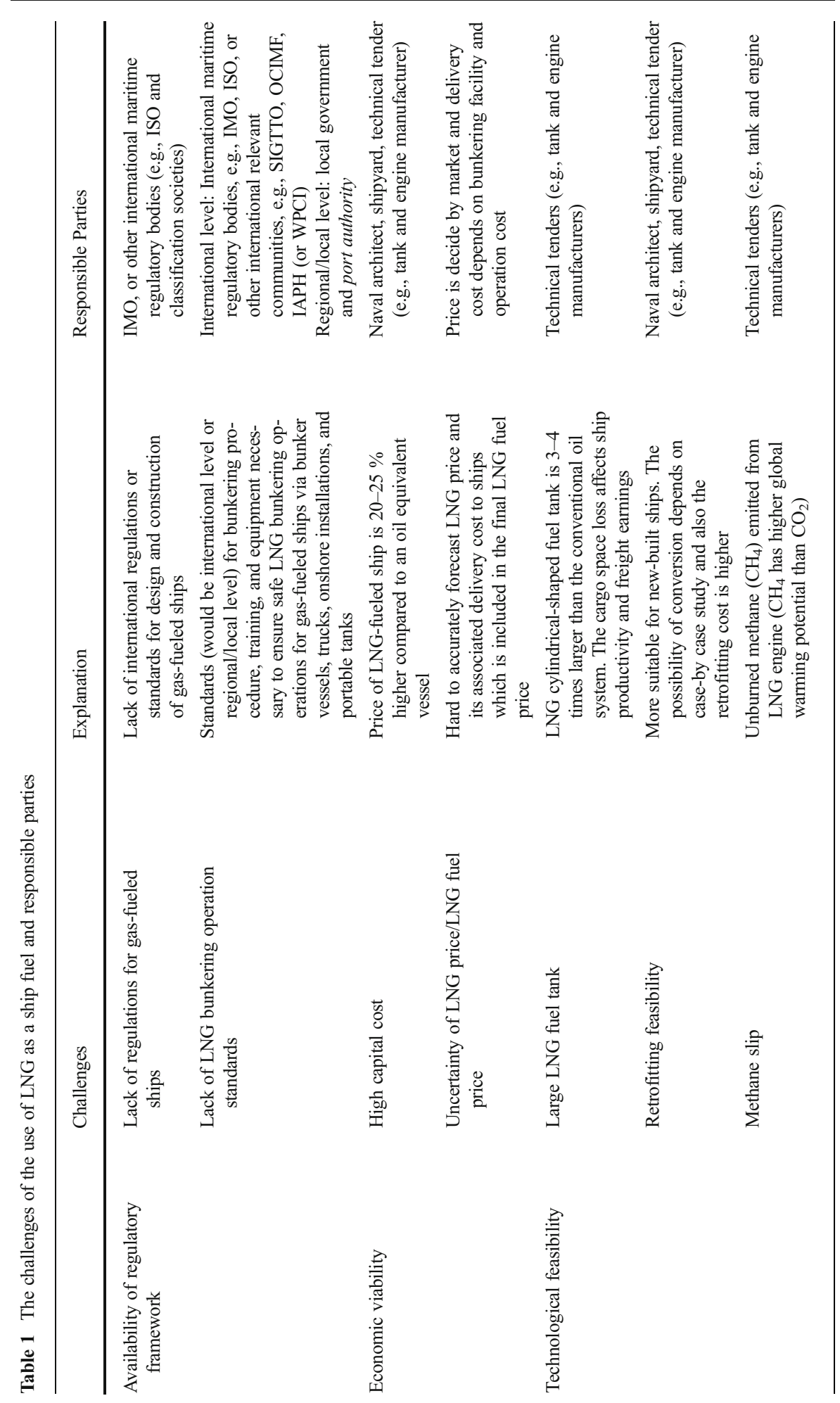




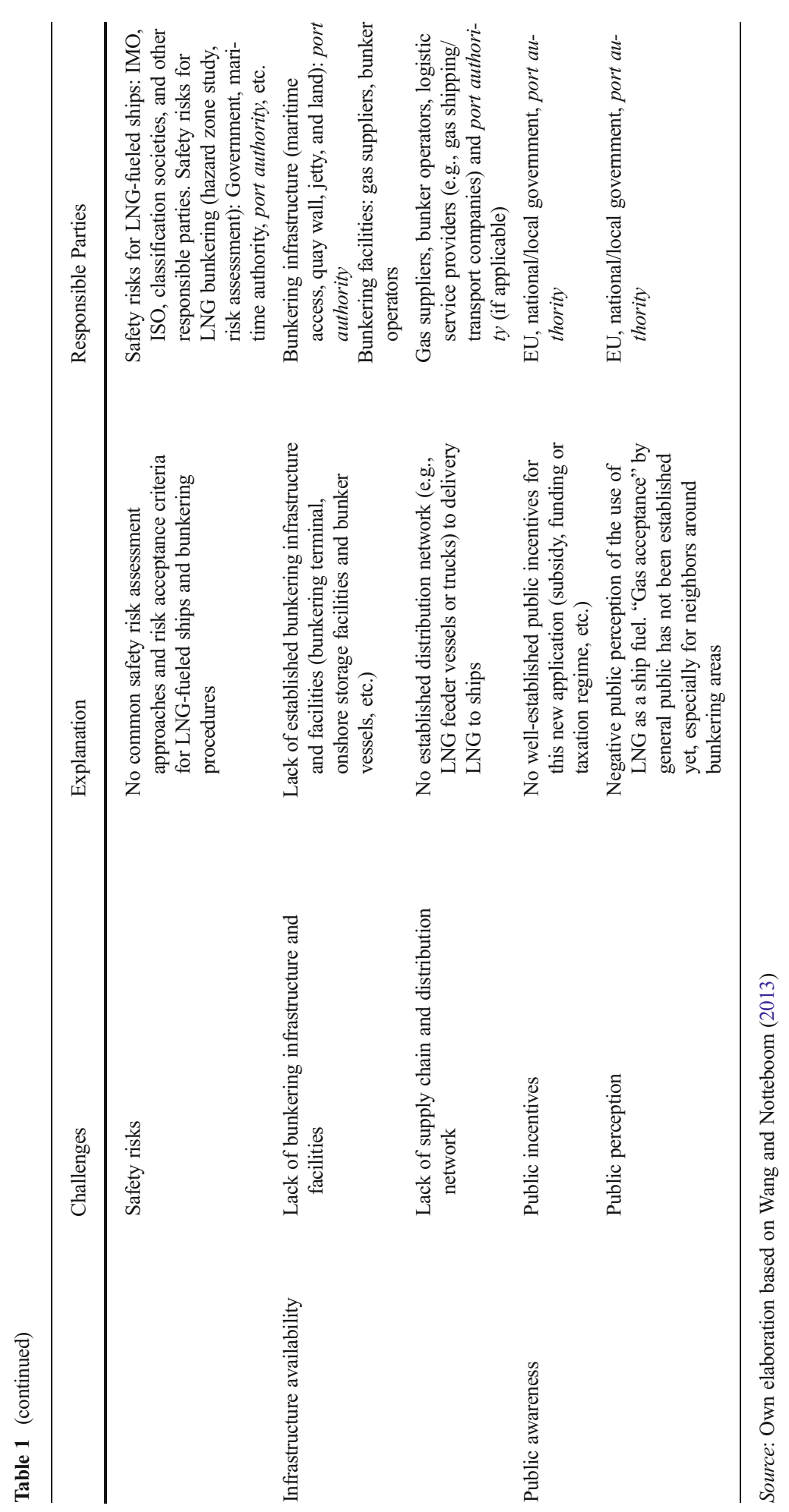


- Lastly, port authorities could act as proactive community managers by sharing knowledge and skills with stakeholders, by lobbying government in view of accelerating permitting processes, and by contributing to a positive public perception in the port community on the use of LNG as a ship fuel.

In section 3, we present the detailed empirical results of the multiple-case study on the eight North European ports to examine how these port authorities are currently developing LNG bunkering facilities. These results could modify the above initial assessment and should help in developing a set of port implementation policies on the promotion of LNG as a marine fuel in the shipping industry.

\section{Findings and discussion}

\subsection{General information of the eight ports}

The selected eight ports all share the traditional "Hanseatic" culture which features the municipal governance (Verhoeven 2010). Although the eight ports enjoy the same governance culture, they vary in port size, type, institutional structure, and environmental strategies. Table 2 provides a brief overview of the eight ports (see more detail in Appendix 2). Six of the eight port authorities are public limited companies. As a result of a port reform process involving deregulation, commercialization, or corporatization, they enjoy more autonomy on managerial and regulatory issues of port development. Bremen and Helsingborg have two entities in charge of port affairs: one is the public port authority which is a department of the municipal government, mainly responsible for administrative and regulatory matters; the other is a limited port management company fully owned by the city, taking charge of development, management, and maintenance of the port area and infrastructure. The environmental performance is a key element in the strategy of the sample ports. The concepts of green, "clean," and "sustainable" are implemented in view of upgrading the port's social responsibility as well as gaining competitive advantage. The environmental initiatives in the field of energy efficiency can be classified into four groups: (1) developing renewable energy, like wind, solar, and biomass; (2) using onshore electricity for ships at berth and operating electric cargo handling machinery and vehicles; (3) promoting an environmental-friendly modal split in hinterland distribution by promoting railway transport and inland shipping; and (4) providing clean fuel for ships, such as low-sulfur fuel oil and LNG, to reduce air emissions. All the eight ports are developing or planning to develop LNG bunkering facilities.

\subsection{The development of LNG bunkering facilities}

Through an extensive review of port documents, we find that these eight ports have different conditions to develop LNG bunkering facilities. It mainly depends on whether the port already had an LNG infrastructure. Table 3 briefly lists existing and planned LNG infrastructure in each port and also the owner/operator of such facilities and the choice of bunkering solutions (see more detail in Appendix 3). Three ports have 


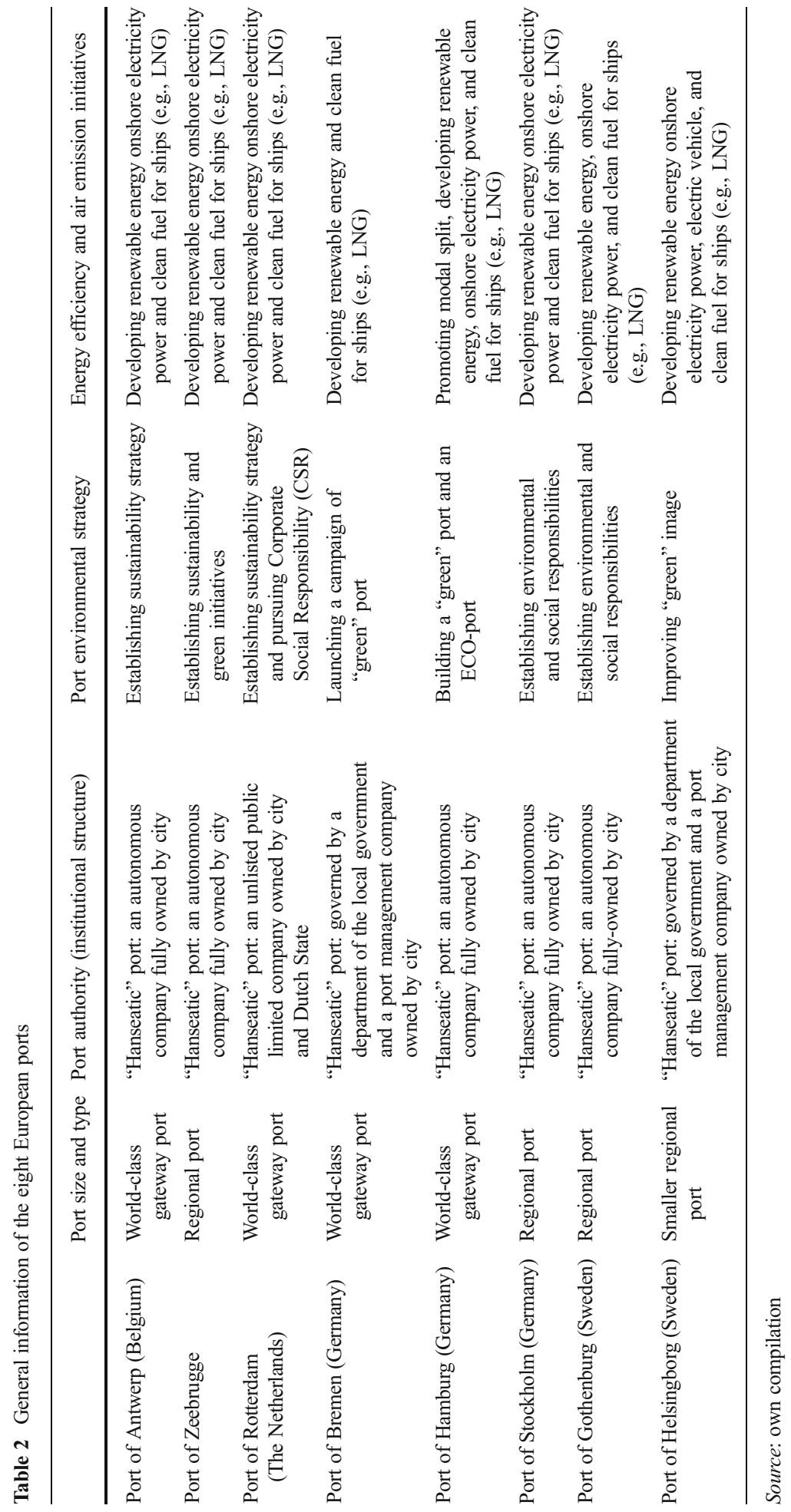




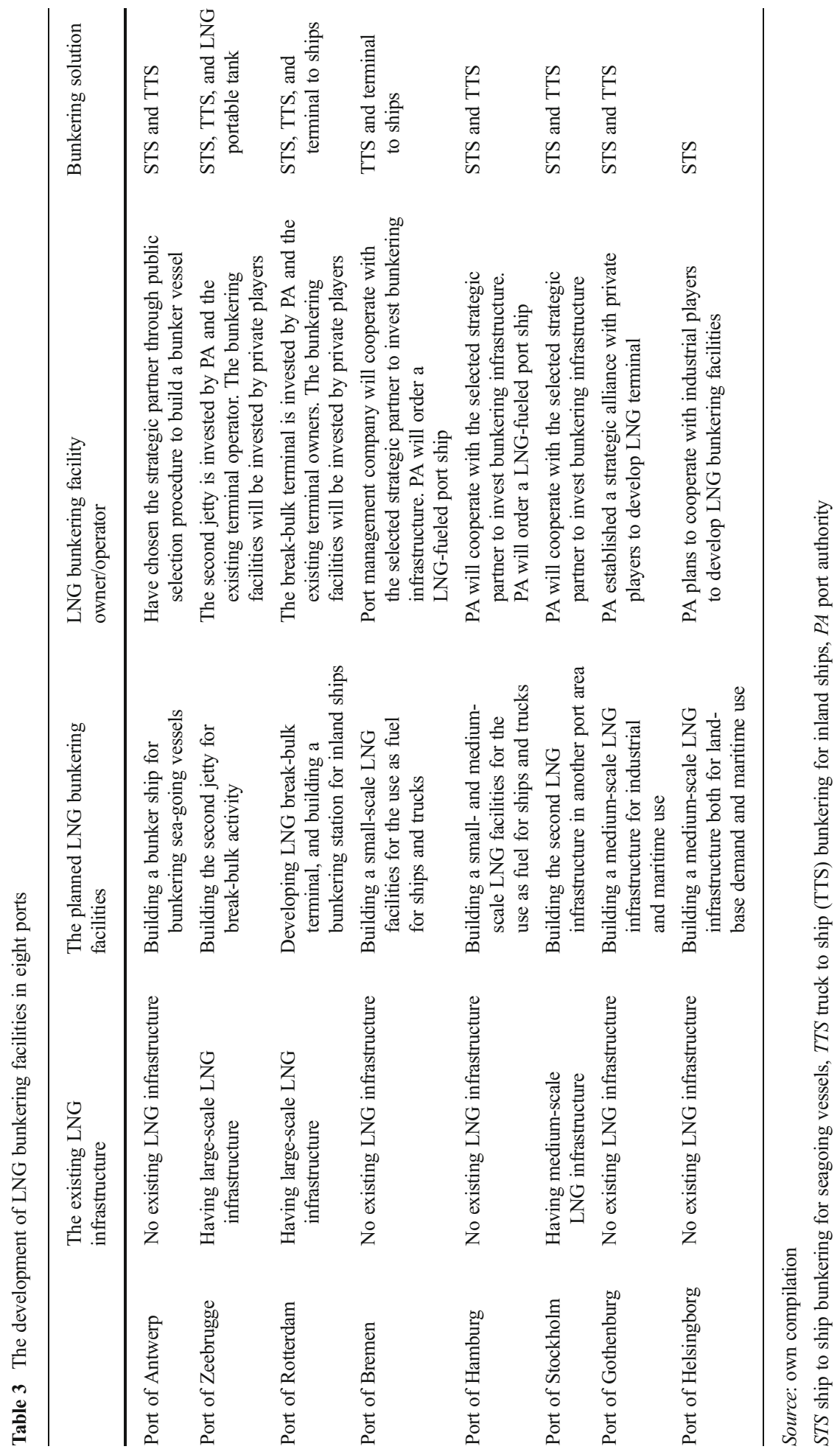


existing LNG infrastructure which could provide a favorable condition for them to develop LNG bunkering operations. The port of Zeebrugge developed one of the earliest LNG import terminal in Europe, while the LNG facilities in Rotterdam and Stockholm are rather new. The large-scale LNG terminals in Rotterdam and Zeebrugge were originally developed to satisfy land-based demand (e.g., power generation, industrial, and residential uses). From its inception, the medium-scale LNG infrastructure in Stockholm was aimed more toward LNG applications including the use of LNG as a transport fuel (i.e., for trucks and ships).

The ports of Zeebrugge and Rotterdam plan to establish LNG break-bulk activities which can not only deal with the LNG bunker demand in their own ports but could also turn the ports into hubs for LNG feeder distribution. The port of Stockholm is planning to build a second LNG terminal in another port area, thereby benefiting from the confidence and experience gained from the current LNG bunkering operations with Viking line. ${ }^{3}$ The other four ports (i.e., Hamburg, Bremen, Gothenburg, and Helsingborg) are planning to construct their first LNG storage facilities for maritime use, while most of them have not yet reached final investment decisions. The port of Antwerp chooses a rather different avenue to start up LNG bunkering operations. In a first development stage, the Antwerp Port authority together with a strategic partner plans to order a bunker vessel instead of building onshore storage facilities, since LNG can be flexibly sourced from the nearby terminals in Zeebrugge and Rotterdam.

The eight ports each have their own development plans on LNG bunkering in line with different market expectations and operational conditions. However, given the capital intensive nature of LNG technology, they all opted for cooperation schemes as a way to share risks and gain confidence for market initiatives. The eight port authorities either have found or are looking for strategic partners to develop LNG bunkering facilities together. These strategic partners are mainly private industrial players, for instance, gas suppliers, bunkering operators, or gas shipping companies, who are the key investors and operators of the LNG bunker supply chain. In order to kick-start the market and solve the chicken-and-egg problem, Antwerp took the initiative to invest in a bunker vessel together with its strategic partner. Hamburg and Bremen are aiming to become the first users of LNG bunkering facilities by owning LNG-fueled port vessels.

With respect to the choice of bunkering solutions, most of the ports favor the options of ship to ship (STS) for sea-going vessels and truck to ship (TTS) for inland/small ships. Both the bunker volume and port turnaround time play a role in deciding which option is preferred from an operational point of view. TTS operations have already been successfully tested in Rotterdam and Antwerp, and Stockholm was the first to implement STS. The STS option is a key technology for allowing a large-scale use of LNG as a ship fuel. Most ports have set targets to provide the LNG bunker supply chain for sea-going vessels by 2015 (except for the port of Helsingborg). Figure 2 depicts the timeline of the development phases for the LNG projects in each of the eight ports. The projects move at a different pace and follow a different implementation plan. Still, they

\footnotetext{
${ }^{3}$ Viking line is a Finnish passenger ferry line. It started to operate the first LNG-fuelled passenger ferry, Viking Grace, from January 2013. The ship currently sails between Stockholm and Helsinki on a daily service, and it is bunkered in the port of Stockholm every day via ship to ship.
} 


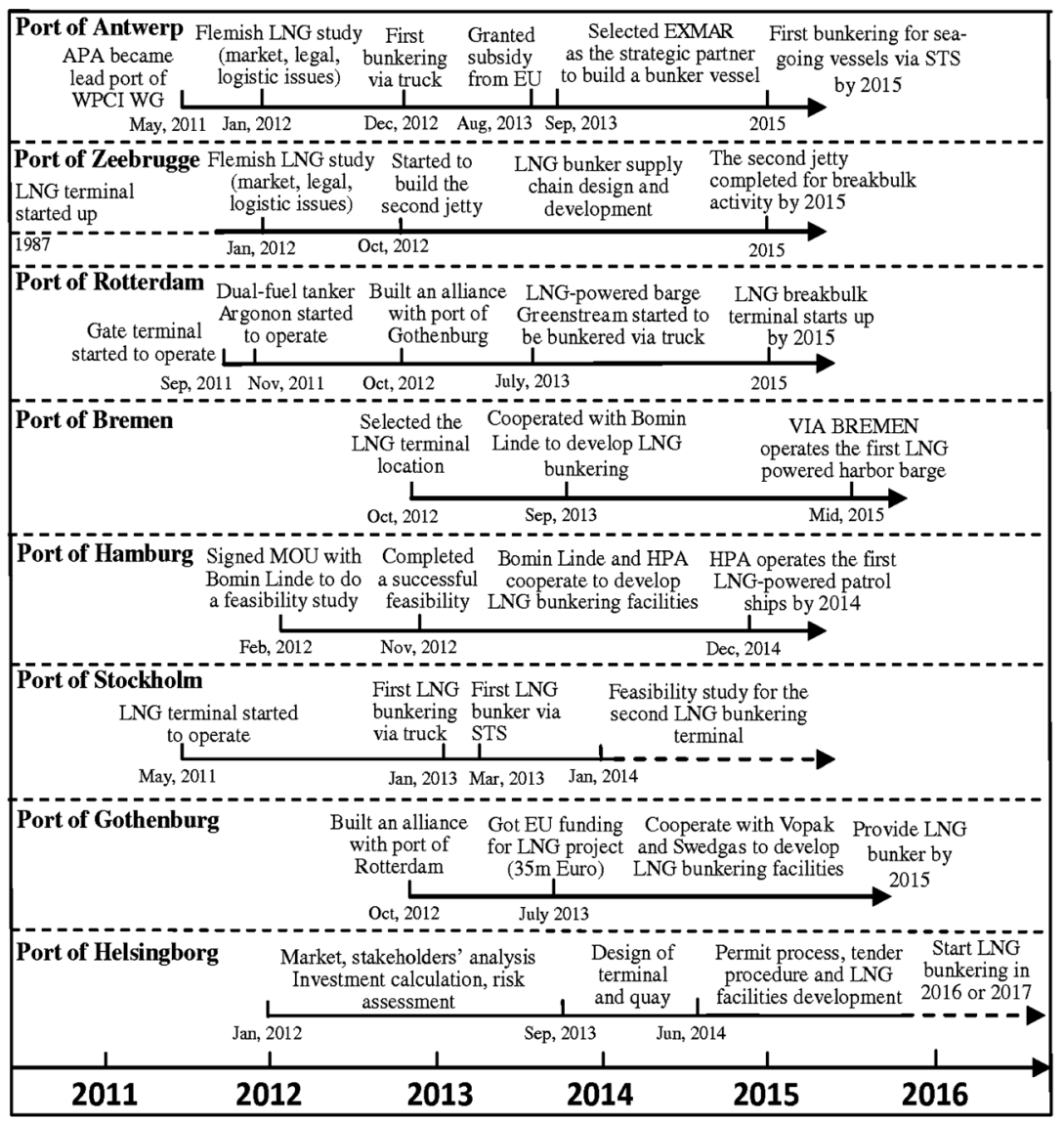

Note: APA: Antwerp port authority.

WPCI WG: World Port Climate Initiative (WPCI) working group for standardizing the port regulations governing LNG. VIABREMEN: the brand name of port management company for port of Bremen

MOU: Memorandum of understanding

HPA: Hamburg port authority

Fig. 2 The timeline of LNG bunkering projects in the eight ports. Source: own compilation

share a common theme aimed at developing favorable policies and incentive schemes to achieve a successful promotion of LNG as a ship fuel. The next section explores such policies in great detail.

\subsection{The role of port authorities in developing LNG bunkering}

In this section, we seek to explore how the eight port authorities promote the use of LNG as a marine fuel and develop bunkering facilities in full length. The following cross-case analysis is guided by the four port functions listed earlier (i.e., landlord, regulator, operator, and community manager) and is mainly based on the data collected from the structured interviews with the senior port representatives who are in charge of the LNG project in their respective ports. 


\subsubsection{Landlord function}

The typical landlord function of port authority in the development of LNG bunkering facilities refers to the provision of land for an LNG bunkering terminal, the construction of quay walls, jetties, or other possible basic infrastructure for maritime access, and the associated development policies. The interviews revealed that most port authorities go beyond the traditional landlord function by adopting "proactive" and "cooperative" policies to speed up the development progress of this new application. These policies relate to (1) a proactive coordinating role in conducting feasibility studies on LNG bunkering in cooperation with various stakeholders (i.e., local government, competent authorities, private actors, etc.), (2) the development of a comprehensive location selection policy, (3) the forging of strategic partnerships with private industrial players and even with other ports for developing LNG bunkering infrastructure, and (4) the adoption of incentive policies to attract investments.

Table 4 uses ticked boxes on a few parameters to show the main trends on how port authority enacts its landlord function to promote the LNG maritime use (see more detail in Appendix 4). All eight port authorities play a proactive coordinating role in performing feasibility studies on LNG bunkering (e.g., technical, regulatory, and market dimensions) together with various stakeholders in order to obtain confidence among market players to kick-start the business. The selection of a location for LNG infrastructure currently is a key problem faced by the ports. The LNG bunkering facilities would be better built close to the customers (e.g., shipping lines), while considering the safety issue of handling LNG as a dangerous cargo, some ports prohibit LNG operations in populated port area. Other ports are however up against the objections from the general public on the construction of LNG facilities near residential areas. Therefore, most of the eight ports together with their strategic partners intend to conduct comprehensive studies to choose the most favorable location for LNG infrastructure by taking into account all the safety, regulatory, social, and economic factors. Since the LNG technology is capital intensive with high risks involved, cooperation is an effective way to reduce/share the uncertainties over availability of infrastructure, LNG demand and price, etc. and to help break the chicken-and-egg market dilemma. The port authorities establish two types of strategic partnerships to promote the maritime use of LNG:The development of strategic alliances with other ports in the region (e.g., the strategic alliance between the ports of Rotterdam and Gothenburg) and even cross-region (e.g., the cooperation among ports of Antwerp, Zeebrugge, and Singapore) on developing LNG infrastructure and the associated safety and technical standards.The establishment of strategic partnerships with private actors, i.e., gas facility investors, terminal operators or gas suppliers, etc., for developing LNG onshore facilities and the bunker supply chain. The port authorities choose strategic partners either via public selection procedures or through private negotiation.

When it comes to investment policy, the port authorities under consideration normally only invest in the basic port infrastructure while superstructures onshore are funded and operated by private actors. However, in the LNG case, some port authorities take the initiative of investing in bunkering facilities with private partners. For example, the port of Antwerp plans to invest in a bunker vessel together with EXMAR. ${ }^{4}$ Also,

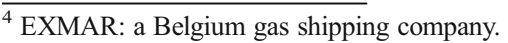




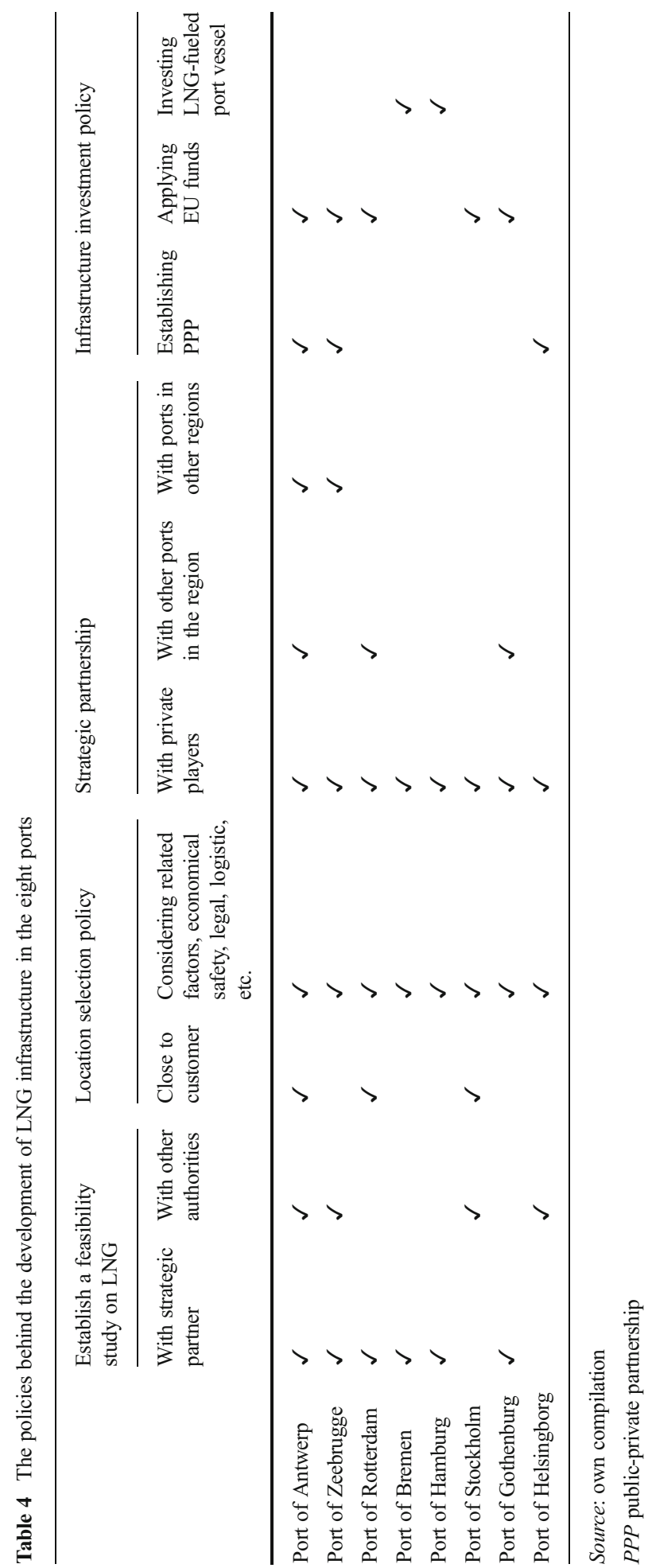


some port authorities are considering public-private partnerships (PPPs) as an alternative tool to promote investments in LNG facilities (e.g., the ports of Zeebrugge and Helsingborg). Quite a few ports proactively apply for EU funds together with private partners (e.g., ports of Rotterdam, Antwerp, and Gothenburg). Hamburg and Bremen plan to invest and operate LNG-powered port vessels by themselves in order to kickstart the market development.

\subsubsection{Regulator function}

The traditional regulator function of port authorities is to passively apply and enforce rules and regulations set by regulatory agencies. However, as the regulations on the use of LNG as a ship fuel are absent at this moment, the development of relevant rules and standards for such new application is key for the wide diffusion of the LNG technology. Table 5 summarizes the regulatory role of the eight ports in this matter. Port authorities mainly adopt a stronger regulatory role in the following ways:

1) By actively assisting regulatory authorities to enforce air emission standards. Some ports even set a monitoring and measuring system to enforce regulatory compliance, e.g., the upcoming IMO strict air emission limits in ECAs.

2) By proactively coordinating and facilitating the development of regulations on the maritime use of LNG and by setting corresponding port bylaws. The relevant regulations and rules on LNG are presently under development in most of the eight ports. The port of Rotterdam is the first port where the LNG bunkering to inland ships is legally regulated.

3) By developing an LNG bunkering checklist and by evaluating risk perimeters. Seven of the eight ports participate in World Ports Climate Initiative (WPCI) working group to jointly develop an LNG bunkering checklist for all possible bunkering solutions (e.g., ship to ship, truck to ship, etc.), to evaluate risk perimeters and to raise public awareness.

4) By setting a differential port tariff on ships fueled by LNG or other clean fuels. The eight ports all adopt a differential port tariff on clean ships. LNG as one of the clean fuels could help shipowners to save operating costs. Six ports of the sample adopted the Environmental Ship Index (ESI), while the ports of Stockholm and Helsingborg developed their own tariff system. Moreover, the port of Stockholm developed a specific incentive regime for ship conversion to $\mathrm{LNG}$.

\subsubsection{Operator function}

Looking at the three traditional functions of port authorities, i.e., the landlord, regulator, and operator functions, it can be concluded from the literature that, as operators, port authorities gradually moved away from providing services of cargo handling, stevedoring and bunkering, etc. These have in most cases been 


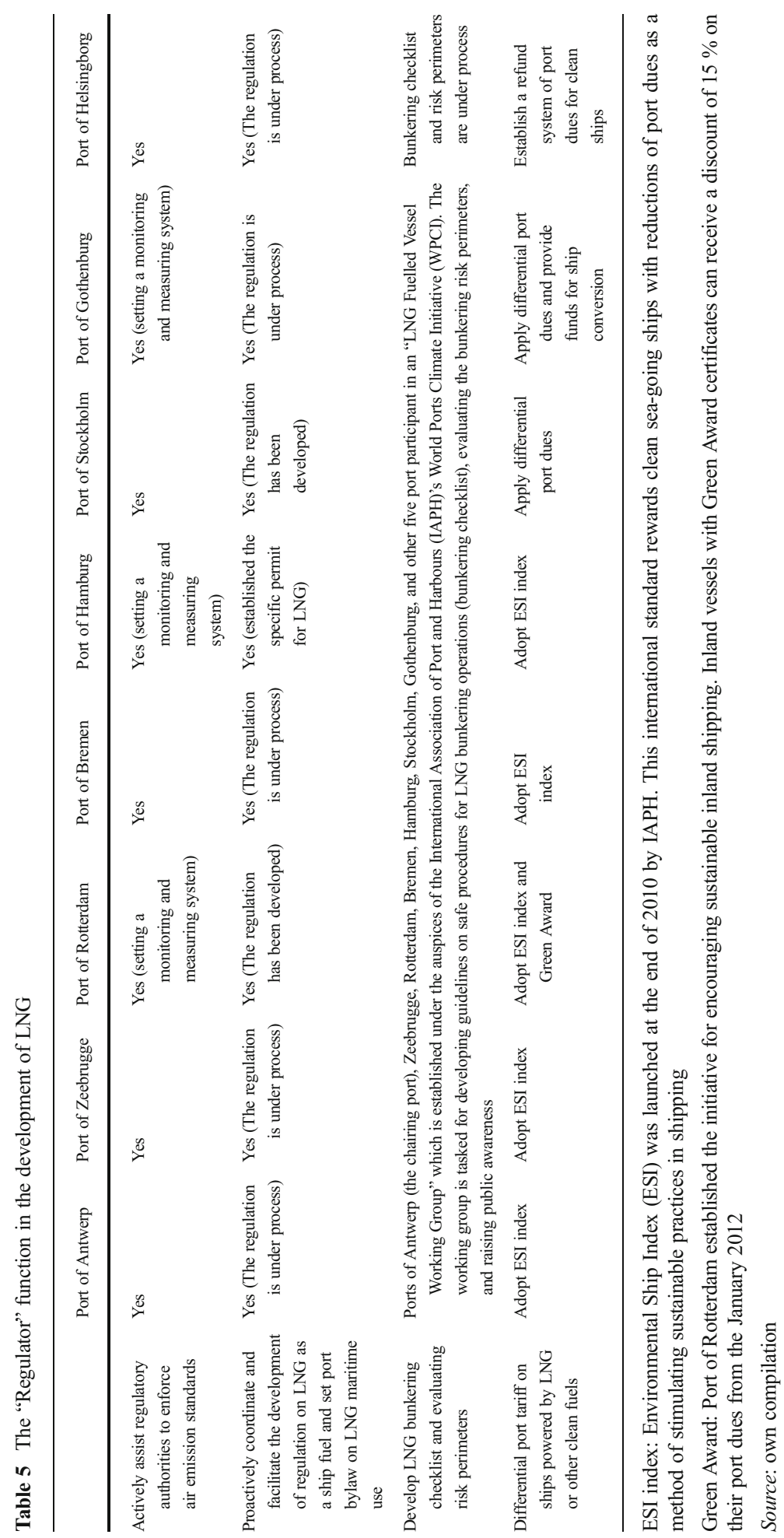


privatized (Verhoeven 2010). The best strategic option for port authorities is to enact an active control and supervision of concessions to stimulate intra-port competition and market contestability as well as sustainable and efficient operations of private operators (De Monie 2004; Notteboom 2007). Thus, LNG bunkering services are supposed to be mainly operated by private actors, although at the beginning of market development, the port authorities might adopt incentive policies to promote investments in the maritime application of LNG.

\subsubsection{Community manager function}

The function of community manager assumes a coordinating role of the port authority to solve collective problems in and outside the port perimeters, for instance, marketing and promoting innovations, etc. Table 6 examines the function of port authorities as community managers in promoting LNG as a ship fuel:Marketing and promotion on the maritime use of LNG. The eight port authorities use different ways to promote and market the maritime use of LNG by organizing conferences, seminars, and workshops or by sending handbooks or arranging meetings with the interested parties.Learning and sharing knowledge and skills with port stakeholders and even other ports. The structured interviews revealed that most of the eight ports intend to enhance interactive learning and knowledge sharing with their stakeholders by establishing various workshops or stakeholder platforms or developing strategic alliances with other ports in/or across the regions. For example, port of Helsingborg collaborates with other six ports in Baltic Sea to encourage interactive learning and promote the use of LNG as a ship fuel. Also, ports of Antwerp, Zeebrugge, and Singapore build a strategic alliance across the regions to sharing knowledge and skills on the development of LNG bunkering infrastructure.Lobbying government and raising public awareness. LNG is regarded as a dangerous cargo which mostly has not been regulated for the use as a ship fuel. Some port authorities play a more proactive role in lobbying the competent governmental authorities and raising the general public awareness in order to facilitate the permitting processes.

\section{Discussion}

The empirical results of the above multiple-case study further demonstrate that port authorities intend to play a more proactive role beyond the traditional landlord and regulator functions in coordinating and facilitating new applications of innovative technologies, e.g., the maritime use of LNG. The proactive and cooperative are the keywords in the development process of LNG bunkering projects in these eight European ports, i.e., from establishing flexibility studies, selecting strategic partners, and developing infrastructure investment policy to conducing safety and risk analysis and guaranteeing all possible bunkering rules and standards legally recorded. It is therefore concluded that the evolving port function beyond the traditional model not only helps to 


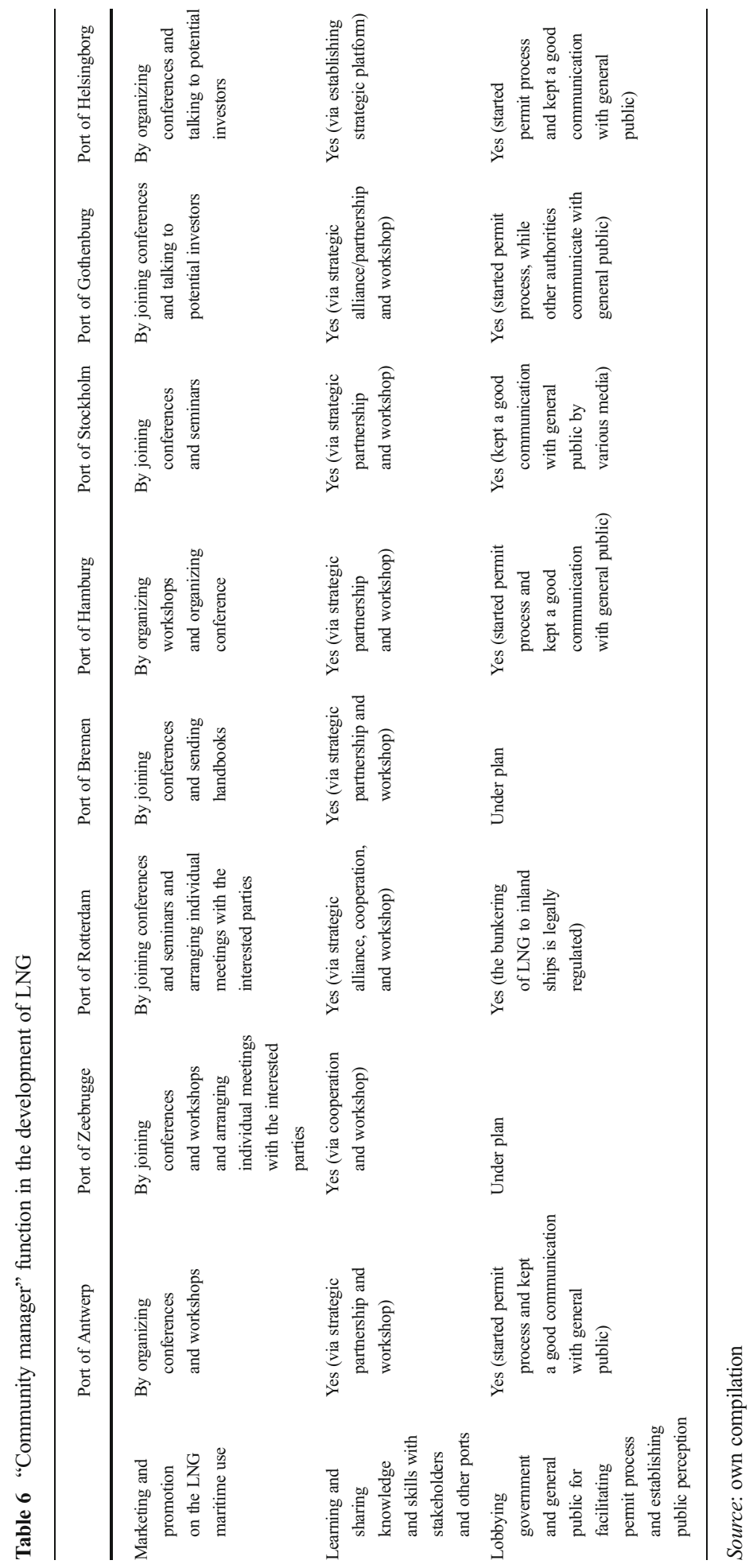


enhance port core competences, e.g., an efficient logistical network and hinterland connections (Notteboom and Winkelmans 2002; Van Der Lugt and De Langen 2007), but also effectively facilitates and promotes innovation, especially when innovative technologies are confronted with a market-based chicken-and-egg problem.

In respect of the emerging community manager function, the literature mainly emphasizes the role of port authorities as "systemic coordinator" in maintaining good relationships with port stakeholders (Chlomoudis et al. 2003; De Langen and Chouly 2004; Van Der Horst and De Langen 2007). However, in this paper, we observe that community manager function can also play an important role in promoting innovation. The eight ports enact their role as community manager in the LNG projects not only in advancing stakeholder relationships by launching marketing and promoting campaigns to industrial players, lobbying competent governmental authorities to accelerate permitting process, and raising general public awareness but also in facilitating and enhancing social cooperation in learning and sharing skills and knowledge among port stakeholders via strategic alliances or stakeholder platforms. It is thus indicated that strengthening social collaboration and communication for promoting innovation in the port could add an additional content to this emerging role of community manager. Moreover, the community manager function also captures the essential role of port authorities in their regional innovation system (RIS). Therefore, enhancing such function could extend the role of port in its RIS.

In addition, the case of LNG points to broader geographical innovation networks involving more than one port authority: for instance, the intraregional cooperation between seven ports in the Baltic Sea (port of Helsingborg is the leading port), the inter-regional collaboration between the ports of Rotterdam and Gothenburg, and the international strategic alliance among the ports of Antwerp, Zeebrugge, and Singapore. The examples therefore indicate that port authorities do not need to establish innovation networks only confined to their port perimeters but can widen cooperation platforms to a rather broad range, e.g., intra- and inter-regional or even across the world. It is believed that a wide innovation network can accelerate knowledge diffusion and market introduction of new technologies in a large context.

\section{Conclusions and research implications}

\subsection{Implications for managerial practice}

It is acknowledged that the stringent ship emission regulations under IMO's MARPOL Annex VI are a main driver for considering LNG as a ship fuel. In order to achieve a green and sustainable philosophy, port authorities not only find their responsibility to quickly adapt to the upcoming strict emission regulations but also intend to rapidly respond to the customers' environmental needs for gaining competitive advantages. 
The detailed discussion on the current port practice of the concerned eight ports in promoting the maritime use of LNG makes it possible to further develop a set of port implementation policies. These policies listed below are proposed by considering not only the initial more theoretical assessment presented in section 2.3 but also the empirical evidence observed by the case study:

1) Cooperative development policy: Port authorities should establish various forms of cooperation with stakeholders in or outside of the port perimeter (such as industrial players, governmental authorities, research centers, and other ports in the region and even cross-region). The cooperation can focus on the development of LNG port infrastructure (e.g., location selection), the assessment of the safety risks of the use of LNG in the port environment, and the development of a set of bunkering standards or guidelines. In addition, close partnerships with industrial actors in conducting commercial feasibility studies (e.g., market demand, logistics, price, etc.) is also a key to success. It is believed that cooperation can enhance interactive learning and knowledge sharing which can reduce the market uncertainty and improve the confidence among market players.

2) Financial incentive policy: The infrastructure investment is the crucial issue in the process of developing LNG as a ship fuel. Port authorities should use various types of financial instruments to promote the market development of LNG facilities, for instance, (a) by building joint ventures or PPPs with private actors to invest in bunkering facilities; (b) by providing funding or applying for subsidies from the EU or local government to support investment; (c) by developing a differential port tariff favoring ships powered by clean fuels, like LNG (e.g., ESI and Green Award), or by providing funding for ship conversion (e.g., in port of Stockholm); and (d) if applicable, by establishing pilot projects, for example, owning LNG-powered port vessels, to kick-start LNG market development and solve the chicken-and-egg problem.

3) Coordinating communication policy: Port authorities should take a proactive coordinating role in view of maintaining a good communication within the port community regarding the development of LNG facilities, for instance, (a) by launching a promotion campaign or by organizing conferences, seminars, or workshops; (b) by building a "stakeholder platform" to share knowledge and skills among various stakeholders; and (c) by lobbying the government and raising public awareness to facilitate the permit process.

The above policies are expected to be helpful also to other ports which are planning to extrude their proactive roles in the promotion and facilitation of the use of LNG as a ship fuel.

\subsection{Contribution to scholarly knowledge}

The findings of the concerned multiple-case study indicate that the promotion of LNG as a ship fuel can offer port authorities a window of opportunity to give an additional content to their emerging role as coordinators or facilitators in developing an innovation network in the port community. Therefore, we conclude the following three points to 
stress the role of the evolving port function beyond the traditional model in promoting innovation:

1. A more proactive role of port authorities beyond the traditional landlord and regulator functions could effectively facilitate and promote innovation.

2. The emerging function of port authorities as community manager also plays an important role in promoting innovation by enhancing social cooperation, interactive learning, and knowledge sharing in the port community. This evolving function captures and extrudes the essential role of port authorities in their regional innovation system (RIS).

3. Port authorities could establish a broad innovation network beyond their port perimeters, e.g., strengthening cooperation across regions or over the world, in order to accelerate knowledge diffusion and market introduction of new technologies in a global context.

\subsection{Limitations}

The multiple-case study in this chapter includes eight ports within the two European ECAs (the Baltic Sea and the North Sea ECAs). The limited number of port samples in the confined geographic area affects the level of generalization achieved by the research. Further, the proposed set of port implementation policies which mainly reflects the current practice of the concerned eight ports may limit its application scope on the promotion of the LNG maritime use in a larger context. However, the above limitation suggests for future research which could include other ports (e.g., the eight ports are not included in this study) in the European ECAs, ports in other ECAs (e.g., Northern American ECA) and even the pioneer ports in non-ECA areas. This could supplement and enrich the above proposed port policies and then broaden their application scope to a global context.

\section{Appendix 1: The list of Interviewees}

Eight interviewees from eight North European ports are listed as below

\begin{tabular}{|c|c|c|}
\hline Port authority & Contact person & Department/position \\
\hline Port of Antwerp & Ms. Tessa Major & $\begin{array}{l}\text { Senior Project Manager } \\
\text { Environmental Dept }\end{array}$ \\
\hline Port of Zeebrugge & Mr. Paul Schroé & Environment and zone planning \\
\hline Port of Rotterdam & Ms. Ankie Janssen & $\begin{array}{l}\text { Business Developer Gas and Power } \\
\text { at Port of Rotterdam }\end{array}$ \\
\hline Port of Hamburg & Mr. Hendrik Hollstein & Deputy of Environmental Strategy \\
\hline Ports of Bremen & Ms. Bjela Koenig & Master Mariner and Expert for maritime sustainability \\
\hline Port of Gothenburg. Sweden & Ms. Jill Soderwall & Vice President Business Area Energy and Cruise \\
\hline
\end{tabular}




Port authority Contact person Department/position

$\begin{array}{lll}\text { Ports of Stockholm, Sweden } & \text { Ms. Sandra Gegerfelt } & \text { Public Affairs/Development, Activity Leader } \\ \text { Port of Helsingborg, Sweden } & \text { Mr. Per Olof Jansson } & \text { LNG Project Leader }\end{array}$

\section{Appendix 2: General information of the eight European ports}

\begin{tabular}{|c|c|c|c|c|}
\hline & Port general information & $\begin{array}{l}\text { Port authority (institutional } \\
\text { structure) }\end{array}$ & $\begin{array}{l}\text { Port environmental } \\
\text { strategy }\end{array}$ & $\begin{array}{l}\text { Energy efficiency and } \\
\text { air emission initiatives }\end{array}$ \\
\hline $\begin{array}{l}\text { Port of Antwerp } \\
\text { (Belgium) }\end{array}$ & $\begin{array}{l}\text { The second largest } \\
\text { (gateway) } \\
\text { port in Europe with } \\
\text { excellent } \\
\text { hinterland connec- } \\
\text { tion. In } 2012 \\
\text { about } 184 \text { million } \\
\text { tons of various } \\
\text { kinds of goods were } \\
\text { handled. }\end{array}$ & $\begin{array}{l}\text { Port authority was established } \\
\text { in } \\
1997 \text { as an autonomous } \\
\text { company } \\
\text { fully-owned by City of } \\
\text { Antwerp. } \\
\text { It operates in "landlord" } \\
\text { port model. }\end{array}$ & $\begin{array}{l}\text { Sustainability is the } \\
\text { unifying } \\
\text { theme for Antwerp } \\
\text { port where } \\
\text { the } 3 \text { P's (people, } \\
\text { profit, and } \\
\text { Planet) play a key } \\
\text { role. The first } \\
\text { sustainability report } \\
\text { was published } \\
\text { in } 2010 \text {. }\end{array}$ & $\begin{array}{l}\text { Wind, solar, biomass, } \\
\text { combined } \\
\text { heat and power } \\
\text { (CHP), industrial } \\
\text { residual heat, } \\
\text { onshore electricity } \\
\text { power for barges, } \\
\text { LNG as a } \\
\text { ship fuel. }\end{array}$ \\
\hline $\begin{array}{l}\text { Port of Zeebrugge } \\
\text { (Belgium) }\end{array}$ & $\begin{array}{l}\text { One of the fastest } \\
\text { growing sea ports } \\
\text { in the range of ports } \\
\text { between Le } \\
\text { Havre and Hamburg. } \\
\text { In 2012, } \\
43.8 \text { million tons of } \\
\text { cargo was } \\
\text { handled. RoRo } \\
\text { cargo, food, } \\
\text { and LNG are the } \\
\text { main cargo } \\
\text { handled in the port. }\end{array}$ & $\begin{array}{l}\text { Port authority (MBZ.nv) was } \\
\text { established } \\
\text { in } 1895 \text { as an } \\
\text { autonomous company } \\
\text { fully owned by City of } \\
\text { Bruges. It } \\
\text { operates in "landlord" } \\
\text { port model. }\end{array}$ & $\begin{array}{l}\text { Port of Zeebrugge focuses } \\
\text { on } \\
\text { sustainability and } \\
\text { green initiatives. } \\
\text { It wants to build a } \\
\text { "clean" port } \\
\text { where green energy } \\
\text { could be } \\
\text { largely used. }\end{array}$ & $\begin{array}{l}\text { Wind energy, onshore } \\
\text { electricity } \\
\text { supply, Ecological } \\
\text { foot print to } \\
\text { decrease the } \\
\mathrm{CO}_{2} \text { emission. } \\
\text { LNG as a ship fuel. }\end{array}$ \\
\hline $\begin{array}{l}\text { Port of Rotterdam } \\
\text { (TheNetherlands) }\end{array}$ & $\begin{array}{l}\text { The largest (gateway) } \\
\text { port in Europe } \\
\text { and also the largest } \\
\text { Logistics and } \\
\text { industrial hub in Eu- } \\
\text { rope. In } 2012 \text {, } \\
442 \text { million tons of a } \\
\text { variety of } \\
\text { goods were handled. }\end{array}$ & $\begin{array}{l}\text { Port authority is an unlisted } \\
\text { public limited } \\
\text { company established in } \\
\text { 2004. The city } \\
\text { of Rotterdam holds } 71 \% \\
\text { shares and } \\
\text { Dutch State holds } 29 \% \text {. It } \\
\text { operates } \\
\text { in "landlord" port model. }\end{array}$ & $\begin{array}{l}\text { Port of Rotterdam wants } \\
\text { to be the leader } \\
\text { both in efficiency and } \\
\text { sustainability } \\
\text { and seeks balance } \\
\text { between economy, } \\
\text { people and } \\
\text { environment. } \\
\text { corporate } \\
\text { social responsibility } \\
\text { (CSR) is } \\
\text { an essential element } \\
\text { of port culture }\end{array}$ & $\begin{array}{l}\text { Wind, solar, biomass, } \\
\mathrm{CO}_{2} \text { capture } \\
\text { and storage, shore- } \\
\text { based power, } \\
\text { electronic vehicle } \\
\text { Rotterdam } \\
\text { Incentive scheme for } \\
\text { clean inland } \\
\text { shipping, LNG as a } \\
\text { ship. fuel. }\end{array}$ \\
\hline $\begin{array}{l}\text { Port of Bremen } \\
\text { (Germany) }\end{array}$ & $\begin{array}{l}\text { Port of Bremen (has two } \\
\text { ports: Bremerhaven }\end{array}$ & $\begin{array}{l}\text { The twin ports has one port } \\
\text { authority which is } a\end{array}$ & $\begin{array}{l}\text { Port of Bremen has } \\
\text { launched a campaign }\end{array}$ & $\begin{array}{l}\text { Wind, solar, ship to ship } \\
\text { power }\end{array}$ \\
\hline
\end{tabular}




\begin{tabular}{|c|c|c|c|c|}
\hline & Port general information & $\begin{array}{l}\text { Port authority (institutional } \\
\text { structure) }\end{array}$ & $\begin{array}{l}\text { Port environmental } \\
\text { strategy }\end{array}$ & $\begin{array}{l}\text { Energy efficiency and } \\
\text { air emission } \\
\text { initiatives }\end{array}$ \\
\hline & $\begin{array}{l}\text { and Bremen port) is } \\
\text { the 6th largest port in } \\
\text { Europe. In 2012, the } \\
\text { total port throughput } \\
\text { is } 85 \text { million tons. It } \\
\text { becomes the crucial } \\
\text { container port and } \\
\text { automotive } \\
\text { logistic hub in } \\
\text { Europe. }\end{array}$ & $\begin{array}{l}\text { department of the local } \\
\text { government of Bremen } \\
\text { City. Port management } \\
\text { Company (Bremenports } \\
\text { GmbH\&Co.) is a limited } \\
\text { company } 100 \% \\
\text { owned by City of } \\
\text { Bremen. It } \\
\text { operates in "landlord" } \\
\text { port model. }\end{array}$ & $\begin{array}{l}\text { of "green" port. It } \\
\text { spares no efforts to } \\
\text { protect environment } \\
\text { for every port } \\
\text { development and } \\
\text { expansion planning. }\end{array}$ & $\begin{array}{l}\text { and low sulfur fuel } \\
\text { oil, LNG } \\
\text { as a ship fuel. }\end{array}$ \\
\hline $\begin{array}{c}\text { Port of Hamburg } \\
\text { (Germany) }\end{array}$ & $\begin{array}{l}\text { Port of Hamburg is the } \\
\text { third largest } \\
\text { port and the second } \\
\text { largest container } \\
\text { port in Europe. In } \\
2012 \text {, the total port } \\
\text { throughput is } \\
130.9 \text { million tons. } \\
\text { Hamburg } \\
\text { is Europe's No.1 } \\
\text { railway port. }\end{array}$ & $\begin{array}{l}\text { Hamburg Port Authority is a } \\
\text { limited company } \\
\text { fully owned by the City of } \\
\text { Hamburg. It was } \\
\text { established under public } \\
\text { law in } 2005 \text {. It } \\
\text { operates in "landlord" } \\
\text { port model. }\end{array}$ & $\begin{array}{l}\text { The "green" port is a } \\
\text { declared aim } \\
\text { of port of Hamburg. } \\
\text { It is a founder } \\
\text { member of ECO- } \\
\text { ports, } \\
\text { a network of } 150 \\
\text { European ports } \\
\text { promoting } \\
\text { communication and } \\
\text { the } \\
\text { exchange of } \\
\text { information on } \\
\text { environmental } \\
\text { questions. }\end{array}$ & $\begin{array}{l}\text { The modal split } \\
\text { (strengthen the } \\
\text { railway and inland } \\
\text { waterway } \\
\text { shipping), wind, } \\
\text { solar, electronic } \\
\text { vehicle, onshore } \\
\text { power, low sulfur } \\
\text { fuel oil, LNG as a } \\
\text { ship fuel. }\end{array}$ \\
\hline $\begin{array}{l}\text { Port of Stockholm } \\
\text { (Sweden) }\end{array}$ & $\begin{array}{l}\text { Port of Stockholm is the } \\
\text { one of important } \\
\text { ports in Baltic sea } \\
\text { area. In 2012, } 12 \\
\text { million passengers } \\
\text { traveled and } \\
8 \text { million tons of } \\
\text { goods were shipped. } \\
\text { The port has three } \\
\text { port areas. }\end{array}$ & $\begin{array}{l}\text { The port authority, } \\
\text { Stockholms Hamm AB, } \\
\text { is a } \\
\text { limited company fully- } \\
\text { owned by City of } \\
\text { Stockholm. } \\
\text { It has three subsidiaries } \\
\text { which are co-owned by } \\
\text { the local communities. } \\
\text { The port also provides } \\
\text { services for ferry and } \\
\text { freight traffic. }\end{array}$ & $\begin{array}{l}\text { Environmental and social } \\
\text { responsibilities } \\
\text { are a natural part of } \\
\text { Port of Stockholm's } \\
\text { mandate. In } 2012, \\
\text { port of Stockholm } \\
\text { submitted the first } \\
\text { sustainability report. }\end{array}$ & $\begin{array}{l}\text { Wind, solar, biomass, } \\
\text { onshore } \\
\text { electricity power, } \\
\text { LNG as a ship fuel. }\end{array}$ \\
\hline $\begin{array}{l}\text { Port of Gothenburg } \\
\text { (Sweden) }\end{array}$ & $\begin{array}{l}\text { Port of Gothenburg is the } \\
\text { Scandinavia largest } \\
\text { port and the 13th } \\
\text { largest port in } \\
\text { Europe. } \\
\text { In } 2012 \text {, the total } \\
\text { cargo throughput is } \\
40 \text { million tons. }\end{array}$ & $\begin{array}{l}\text { Gothenburg Port Authority, } \\
\text { Göteborgs Hamn AB, } \\
\text { is a company wholly } \\
\text { owned by the City of } \\
\text { Gothenburg, founded in } \\
\text { 2011. It operates in } \\
\text { "landlord" port model. }\end{array}$ & $\begin{array}{l}\text { Four core values the port } \\
\text { of Gothenburg } \\
\text { pursuers: Reliability, } \\
\text { Innovation, } \\
\text { Co-operation, and } \\
\text { Sustainability. } \\
\text { Environmental issues } \\
\text { constitute an } \\
\text { important foundation } \\
\text { for the port. }\end{array}$ & $\begin{array}{l}\text { Onshore power supply, } \\
\text { rail shuttles, } \\
\text { electronic vehicle, } \\
\text { LBG (Liquefied } \\
\text { biogas) /LNG as a } \\
\text { ship fuel. }\end{array}$ \\
\hline $\begin{array}{l}\text { Port of Helsingborg } \\
\text { (Sweden) }\end{array}$ & $\begin{array}{l}\text { Port of Helsingborg is a } \\
\text { small regional port } \\
\text { but is one of the } \\
\text { busiest ports in } \\
\text { Baltic sea area, }\end{array}$ & $\begin{array}{l}\text { The port authority is a } \\
\text { department of city of } \\
\text { Helsingborg. Port } \\
\text { management company, } \\
\text { Helsingborg Hamn AB, is }\end{array}$ & $\begin{array}{l}\text { The port of Helsingborg } \\
\text { pursues its } \\
\text { environmental targets } \\
\text { in order to } \\
\text { improve "green" }\end{array}$ & $\begin{array}{l}\text { The use of LNG and } \\
\text { LBG (Liquefied } \\
\text { biogas) } \\
\text { as a ship Fuel, } \\
\text { onshore power, and }\end{array}$ \\
\hline
\end{tabular}




\begin{tabular}{cccc}
\hline Port general information & $\begin{array}{c}\text { Port authority (institutional } \\
\text { structure) }\end{array}$ & $\begin{array}{c}\text { Port environmental } \\
\text { strategy }\end{array}$ & $\begin{array}{c}\text { Energy efficiency and } \\
\text { air emission } \\
\text { initiatives }\end{array}$ \\
\hline $\begin{array}{l}\text { which has extensive } \\
\text { and diversified cargo } \\
\text { handling facilities. }\end{array}$ & $\begin{array}{l}\text { a limited company } \\
\text { fully owned by the city } \\
\text { founded in 1987. It still } \\
\text { provides services for } \\
\text { container handling } \\
\text { and stevedoring. }\end{array}$ & $\begin{array}{l}\text { image } \text { and corporate } \\
\text { responsibility to the } \\
\text { local community. }\end{array}$ \\
\end{tabular}

Source: own compilation

\section{Appendix 3: The development of LNG bunkering facilities in eight ports}

\begin{tabular}{|c|c|c|c|c|}
\hline & $\begin{array}{l}\text { The existing LNG } \\
\text { infrastructure }\end{array}$ & $\begin{array}{l}\text { The planned LNG bunkering } \\
\text { facilities }\end{array}$ & $\begin{array}{l}\text { LNG bunkering facility } \\
\text { owner/operator }\end{array}$ & Bunkering solution \\
\hline $\begin{array}{l}\text { Port of } \\
\text { Antwerp }\end{array}$ & $\begin{array}{l}\text { No existing LNG } \\
\quad \text { infrastructure }\end{array}$ & $\begin{array}{l}\text { Building a bunker vessel } \\
\text { with strategic partner } \\
\text { mainly for bunkering } \\
\text { sea-going vessels. } \\
\text { Developing intermediary } \\
\text { storage tank or even } \\
\text { liquefied plant later } \\
\text { depends on the market } \\
\text { growth. }\end{array}$ & $\begin{array}{l}\text { After public selection } \\
\text { procedure in Sep, } \\
\text { 2013, EXMAR. } \\
\text { became the strategic } \\
\text { partner of PA to } \\
\text { build a bunker vessel. }\end{array}$ & $\begin{array}{l}\text { Ship to ship (STS) for } \\
\text { seagoing vessels } \\
\text { Truck to ship (TTS) for } \\
\text { inland ships } \\
\text { (the first operation } \\
\text { in Dec, 2012) }\end{array}$ \\
\hline $\begin{array}{l}\text { Port of } \\
\quad \text { Zeebrugge }\end{array}$ & $\begin{array}{l}\text { The LNG terminal } \\
\text { (large-scale) } \\
\text { in Zeebrugge started } \\
\text { to operate in } 1987 \text {, } \\
\text { mainly for land-based } \\
\text { demand, having three } \\
87,000 \mathrm{~m}^{3} \text {, } \\
\text { one } 140,000 \mathrm{~m}^{3} \\
\text { (in 2008) storage } \\
\text { tanks and one jetty. It } \\
\text { serves as an important } \\
\text { gas hub in Europe. }\end{array}$ & $\begin{array}{l}\text { Building the second jetty } \\
\text { for break-bulk activity } \\
\text { which can load LNG feeder } \\
\text { and bunker vessels. The } \\
\text { jetty will come into service } \\
\text { in } 2015 \text {. The LNG truck } \\
\text { filling station up in } 2010 \text {. }\end{array}$ & $\begin{array}{l}\text { The existing LNG } \\
\text { terminal operator is } \\
\text { Fluxys. The second } \\
\text { jetty is invested by } \\
\text { PA and Fluxys for } \\
\text { break-bulk purpose. } \\
\text { The bunkering supply } \\
\text { facilities will be } \\
\text { invested by other } \\
\text { private players. }\end{array}$ & $\begin{array}{l}\text { STS for seagoing } \\
\text { vessels } \\
\text { TTS for inland ships } \\
\text { LNG portable tank } \\
\text { (will start from } \\
\text { 2014) }\end{array}$ \\
\hline $\begin{array}{l}\text { Port of } \\
\text { Rotterdam }\end{array}$ & $\begin{array}{l}\text { The GATE LNG terminal } \\
\text { (large-scale) } \\
\text { started to operate in } \\
\text { 2011, mainly } \\
\text { dealing. It has three } \\
\text { storage } \\
\text { tanks }\left(3 \times 180,000 \mathrm{~m}^{3}\right) \\
\text { and } \\
\text { two jetties. }\end{array}$ & $\begin{array}{l}\text { Developing an LNG break-bulk } \\
\text { terminal, } \\
\text { nest to the Gate terminal } \\
\text { where LNG can } \\
\text { be loaded to bunker vessels } \\
\text { and trucks } \\
\text { for bunkering purpose. Also, } \\
\text { building a } \\
\text { bunkering station in another } \\
\text { port area } \\
\text { especially for inland ships }\end{array}$ & $\begin{array}{l}\text { PA together with Vopak } \\
\text { and Gasunie to develop } \\
\text { LNG break-bulk } \\
\text { terminal. PA provides } \\
\text { basic port infrastruc- } \\
\text { ture, } \\
\text { Vopak and Gasunie in- } \\
\text { vest } \\
\text { onshore facilities. The } \\
\text { bunker supply chain } \\
\text { will }\end{array}$ & $\begin{array}{l}\text { 1. STS for seagoing } \\
\text { vessels } \\
\text { 2. TTS for inland } \\
\text { ships } \\
\text { 3. Terminal to ships } \\
\text { by loading arm } \\
\text { for small or } \\
\text { inland ships (still } \\
\text { under plan) }\end{array}$ \\
\hline
\end{tabular}




\begin{tabular}{|c|c|c|c|c|}
\hline & $\begin{array}{c}\text { The existing LNG } \\
\text { infrastructure }\end{array}$ & $\begin{array}{l}\text { The planned LNG bunkering } \\
\text { facilities }\end{array}$ & $\begin{array}{l}\text { LNG bunkering facility } \\
\text { owner/operator }\end{array}$ & Bunkering solution \\
\hline & & $\begin{array}{l}\text { (still } \\
\text { under plan). }\end{array}$ & $\begin{array}{l}\text { be invested by private } \\
\text { actors. }\end{array}$ & \\
\hline $\begin{array}{l}\text { Port of } \\
\text { Bremen }\end{array}$ & $\begin{array}{l}\text { No existing LNG } \\
\text { infrastructure }\end{array}$ & $\begin{array}{l}\text { Building a small-scale } \\
\text { storage LNG tank } \\
\text { in port, roughly up } \\
\text { to } 500 \mathrm{~m}^{3} \text {, mainly } \\
\text { for the use as a fuel } \\
\text { for maritime and } \\
\text { land vehicles. }\end{array}$ & $\begin{array}{l}\text { Port management } \\
\text { company will cooperate } \\
\text { with Bomin Linde } \\
\text { LNG } \\
\text { who will invest onshore } \\
\text { facilities. The supply } \\
\text { chain will be invested } \\
\text { by } \\
\text { private actors. } \\
\text { However, } \\
\text { PA will order a LNG- } \\
\text { fueled harbor barge to } \\
\text { kick-start the market } \\
\text { demand. }\end{array}$ & $\begin{array}{l}\text { The possible bunkering } \\
\text { solutions are TTS } \\
\text { and Terminal to } \\
\text { Ships, while the } \\
\text { final decision has } \\
\text { not been made. }\end{array}$ \\
\hline $\begin{array}{l}\text { Port of } \\
\qquad \text { Hamburg }\end{array}$ & $\begin{array}{l}\text { No existing LNG } \\
\text { infrastructure }\end{array}$ & $\begin{array}{l}\text { Building a medium or } \\
\text { small scale storage } \\
\text { LNG tank in port, } \\
\text { roughly up to } \\
20,000 \mathrm{~m}^{3} \text { (still } \\
\text { under plan) } \\
\text { particularly for } \\
\text { supplying fuel for } \\
\text { ships and trucks. }\end{array}$ & $\begin{array}{l}\text { PA is together with } \\
\text { Bomin Linde LNG, to } \\
\text { develop LNG } \\
\text { bunkering } \\
\text { terminal. The bunker } \\
\text { supply chain will be } \\
\text { invested by private } \\
\text { actors. However, PA } \\
\text { will } \\
\text { order a LNG-fueled pa- } \\
\text { trol } \\
\text { ship to kick-start the } \\
\text { market demand. }\end{array}$ & $\begin{array}{l}\text { The possible bunkering } \\
\text { solutions are STS } \\
\text { and TTS, while the } \\
\text { study is still } \\
\text { ongoing. }\end{array}$ \\
\hline $\begin{array}{l}\text { Port of } \\
\text { Stockholm }\end{array}$ & $\begin{array}{l}\text { LNG terminal in } \\
\text { Stockholm } \\
\text { (medium-scale) started } \\
\text { to } \\
\text { operate in } 2011 \text {, having } \\
\text { a } \\
\text { storage tank of } \\
20,000 \mathrm{~m}^{3} \\
\text { and one jetties, serving } \\
\text { both } \\
\text { for land-based and } \\
\text { transport } \\
\text { demand. }\end{array}$ & $\begin{array}{l}\text { The exiting LNG } \\
\text { terminal started to } \\
\text { provide LNG to } \\
\text { ships as fuel in Jan, } \\
\text { 2013. Currently, PA } \\
\text { is looking for a new } \\
\text { place in another port } \\
\text { area for building the } \\
\text { second LNG } \\
\text { infrastructure. }\end{array}$ & $\begin{array}{l}\text { The exiting LNG } \\
\text { bunkering } \\
\text { project is developed by } \\
\text { AGA (a gas supplier), } \\
\text { Viking Line (a shipping } \\
\text { line) and PA together. } \\
\text { AGA is the terminal } \\
\text { owner and bunkering } \\
\text { operator. The second } \\
\text { project is still under } \\
\text { plan. }\end{array}$ & $\begin{array}{l}\text { The first port in the } \\
\text { world offered LNG } \\
\text { to ships by STS } \\
\text { in Mar, 2013. The } \\
\text { solution for the } \\
\text { second terminal is } \\
\text { still under } \\
\text { discussion. }\end{array}$ \\
\hline $\begin{array}{l}\text { Port of } \\
\text { Gothenburg }\end{array}$ & $\begin{array}{l}\text { No existing LNG } \\
\text { infrastructure }\end{array}$ & $\begin{array}{l}\text { Building a medium-scale stor- } \\
\text { age LNG tank in } \\
\text { the port, around } \\
10-25,000 \mathrm{~m}^{3} \text {, both for } \\
\text { industrial and maritime } \\
\text { use. }\end{array}$ & $\begin{array}{l}\text { PA established a strategic } \\
\text { alliance with Swedgas } \\
\text { and } \\
\text { Vopak to develop LNG } \\
\text { terminal. The two } \\
\text { private } \\
\text { companies will be the } \\
\text { terminal owners and } \\
\text { operators. }\end{array}$ & $\begin{array}{l}\text { The port will develop } \\
\text { STS } \\
\text { bunkering solution, } \\
\text { but at the } \\
\text { beginning of the } \\
\text { project, TTS } \\
\text { will be used. }\end{array}$ \\
\hline $\begin{array}{l}\text { Port of } \\
\text { Helsingborg }\end{array}$ & $\begin{array}{l}\text { No existing LNG } \\
\text { infrastructure }\end{array}$ & $\begin{array}{l}\text { Building a medium-scale stor- } \\
\text { age LNG tank in }\end{array}$ & $\begin{array}{l}\text { PA plans to cooperate } \\
\text { with other stakeholders, }\end{array}$ & $\begin{array}{c}\text { The port wants to } \\
\text { develop STS }\end{array}$ \\
\hline
\end{tabular}




\begin{tabular}{llll}
\hline $\begin{array}{c}\text { The existing LNG } \\
\text { infrastructure }\end{array}$ & $\begin{array}{c}\text { The planned LNG bunkering } \\
\text { facilities }\end{array}$ & $\begin{array}{c}\text { LNG bunkering facility } \\
\text { owner/operator }\end{array}$ & Bunkering solution \\
\hline port, around $15,000 \mathrm{~m}^{3}$, & $\begin{array}{l}\text { like gas supplier, } \\
\text { shipowner, etc., to } \\
\text { both for land-base } \\
\text { demand and maritime } \\
\text { use. }\end{array}$ & $\begin{array}{l}\text { bunkering solution, } \\
\text { which is regarded } \\
\text { together. }\end{array}$ & as a flexible option. \\
\end{tabular}

The underlined words mean private entities, such as LNG facility invest/owner/operator (like Fluxys, Vopak, Gasunie, Bomin Linde, AGA, Swedgas), gas shipping company (EXMAR), and shipping line (Viking line). Source: own compilation

$P A$ port authority

\section{Appendix 4: The policies behind the development of LNG infrastructure in the eight ports}

\begin{tabular}{|c|c|c|c|c|}
\hline & $\begin{array}{l}\text { Establish a feasibility } \\
\text { study on LNG }\end{array}$ & Location selection policy & Strategic partnership & $\begin{array}{l}\text { Infrastructure investment } \\
\text { policy }\end{array}$ \\
\hline $\begin{array}{l}\text { ort of } \\
\text { Antwerp }\end{array}$ & $\begin{array}{l}\text { Together with Flemish } \\
\text { government and } \\
\text { other Belgian ports } \\
\text { (Zeebrugge, Gent) } \\
\text { conducted a feasibility } \\
\text { study. Also, PA } \\
\text { plans to do a } \\
\text { commercial study } \\
\text { with } \\
\text { its strategic partner } \\
\text { later. }\end{array}$ & $\begin{array}{l}\text { No onshore facility needed } \\
\text { for bunkering } \\
\text { sea-going ships via STS, } \\
\text { while the } \\
\text { location of inland barge } \\
\text { bunker station } \\
\text { is still under decision } \\
\text { considering all } \\
\text { related factors } \\
\text { (economical, safety, } \\
\text { logistic, etc.). }\end{array}$ & $\begin{array}{l}\text { 1. Establishing strategic } \\
\text { alliance with port } \\
\text { of Rotterdam to develop } \\
\text { port infrastructure } \\
\text { of inland barge bunker } \\
\text { station. } \\
\text { 2. Cooperating with ports of } \\
\text { Zeebrugge } \\
\text { and Singapore on LNG } \\
\text { infrastructure. } \\
\text { 3. Through public selection } \\
\text { establishing } \\
\text { strategic partnership with } \\
\text { EXMAR to } \\
\text { build a bunker vessel. }\end{array}$ & $\begin{array}{l}\text { 1. Establishing public private } \\
\text { partnership } \\
\text { (PPP) with EXMAR } \\
\text { investing in a } \\
\text { bunker vessel. } \\
\text { 2. Besides providing basic } \\
\text { port } \\
\text { infrastructure, PA got EU } \\
\text { funding for } \\
\text { barge bunker station } \\
\text { which could also } \\
\text { support private } \\
\text { investment. }\end{array}$ \\
\hline $\begin{array}{l}\text { Port of } \\
\text { Zeebrugge }\end{array}$ & $\begin{array}{l}\text { Together with Flemish } \\
\text { government and } \\
\text { other Belgian ports } \\
\text { (Antwerp, Gent), } \\
\text { conducted a feasibility } \\
\text { study, and also } \\
\text { cooperated with other } \\
\text { stakeholders to } \\
\text { work on several pilot } \\
\text { projects. }\end{array}$ & $\begin{array}{l}\text { No bunkering terminal } \\
\text { planned currently, } \\
\text { as the bunkering } \\
\text { operation mainly via } \\
\text { STS by the bunker vessel } \\
\text { loaded LNG } \\
\text { in the second jetty. }\end{array}$ & $\begin{array}{l}\text { 1. Establishing cooperation } \\
\text { with ports } \\
\text { of Zeebrugge and } \\
\text { Singapore on the } \\
\text { development of LNG } \\
\text { infrastructure. } \\
\text { 2. Together with Fluxys to } \\
\text { develop the } \\
\text { second jetty. } \\
\text { 3. Looking for strategic } \\
\text { partners to build } \\
\text { bunker supply chain. }\end{array}$ & $\begin{array}{l}\text { 1. PA provides basic port } \\
\text { infrastructure for } \\
\text { the second jetty, and } \\
\text { Fluxys invests others. } \\
\text { 2. Possibly investing in } \\
\text { bunker vessel with } \\
\text { private actors, or } \\
\text { providing funding for } \\
\text { other bunkering } \\
\text { solutions, like trucks, } \\
\text { LNG portable tanks (still } \\
\text { under discussion). }\end{array}$ \\
\hline $\begin{array}{l}\text { Port of } \\
\text { Rotterdam }\end{array}$ & $\begin{array}{l}\text { Cooperating with strategic } \\
\text { partners to } \\
\text { conduct a feasibility }\end{array}$ & $\begin{array}{l}\text { The location of break-bulk } \\
\text { terminal has been } \\
\text { selected just next to the }\end{array}$ & $\begin{array}{l}\text { 1. Establishing strategic } \\
\text { alliance with port of }\end{array}$ & $\begin{array}{l}\text { PA invests in the LNG } \\
\text { infrastructure but } \\
\text { investment of onshore }\end{array}$ \\
\hline
\end{tabular}




\begin{tabular}{|c|c|c|c|c|}
\hline & $\begin{array}{c}\text { Establish a feasibility } \\
\text { study on LNG }\end{array}$ & Location selection policy & Strategic partnership & $\begin{array}{l}\text { Infrastructure investment } \\
\text { policy }\end{array}$ \\
\hline & $\begin{array}{l}\text { study on the } \\
\text { development of break- } \\
\text { bulk terminal } \\
\text { and inland barge bun- } \\
\text { ker station. }\end{array}$ & $\begin{array}{l}\text { Gate LNG terminal } \\
\text { easily for break-bulk ac- } \\
\text { tivities. The barge } \\
\text { bunker station has also } \\
\text { been chosen in } \\
\text { the inner port area close } \\
\text { to barge } \\
\text { operation place. }\end{array}$ & $\begin{array}{l}\text { Antwerp for inland barge } \\
\text { bunker station. } \\
\text { 2. Establishing strategic } \\
\text { alliance with port } \\
\text { of Gothenburg on LNG } \\
\text { infrastructure. } \\
\text { 3. Together with Vopak and } \\
\text { Gasunie to develop LNG } \\
\text { break-bulk terminal. }\end{array}$ & $\begin{array}{l}\text { bunkering facilities } \\
\text { mainly come from private } \\
\text { actors, while } \\
\text { PA got EU funds (around } \\
74 \text { million } \\
\text { Euro) for the LNG } \\
\text { projects. }\end{array}$ \\
\hline $\begin{array}{l}\text { Port of } \\
\text { Bremen }\end{array}$ & $\begin{array}{l}\text { Port management } \\
\text { company together } \\
\text { with PA and other } \\
\text { competent } \\
\text { authorities to conduct } \\
\text { infrastructure } \\
\text { study, while the } \\
\text { commercial } \\
\text { study mainly done by } \\
\text { private actors. }\end{array}$ & $\begin{array}{l}\text { The location has been } \\
\text { selected } \\
\text { via working with various } \\
\text { stakeholders, and } \\
\text { considering } \\
\text { maritime access, logistic, } \\
\text { regulatory, and safety } \\
\text { factors. }\end{array}$ & $\begin{array}{l}\text { Together with strategic } \\
\text { partner, Bomin Linde } \\
\text { LNG, to develop LNG } \\
\text { bunkering facilities. }\end{array}$ & $\begin{array}{l}\text { The port provides the basic } \\
\text { port } \\
\text { infrastructure, while } \\
\text { onshore } \\
\text { facilities and supply } \\
\text { chain will } \\
\text { be invested by Bomin } \\
\text { Linde. PA } \\
\text { plans to invest a LNG- } \\
\text { fueled } \\
\text { port ship to kick start } \\
\text { market } \\
\text { demand. }\end{array}$ \\
\hline $\begin{array}{l}\text { Port of } \\
\text { Hamburg }\end{array}$ & $\begin{array}{l}\text { PA together with Linde } \\
\text { Group } \\
\text { conducted a } \\
\text { comprehensive } \\
\text { feasibility study in the } \\
\text { early of } 2012 \text {. }\end{array}$ & $\begin{array}{l}\text { The location has been chosen } \\
\text { next to the existing oil } \\
\text { terminal, } \\
\text { by considering safety and } \\
\text { regulatory factors. }\end{array}$ & $\begin{array}{l}\text { Together with strategic } \\
\text { partner, Bomin Linde } \\
\text { LNG, to develop LNG } \\
\text { bunkering facilities. }\end{array}$ & $\begin{array}{l}\text { PA invests the basic port } \\
\text { infrastructure, } \\
\text { while the onshore facility } \\
\text { and supply } \\
\text { chain will be invested by } \\
\text { Bomin Linde. } \\
\text { PA plans to invest a } \\
\text { LNG-fueled port } \\
\text { ship to kick start market } \\
\text { demand. }\end{array}$ \\
\hline $\begin{array}{l}\text { Port of } \\
\text { Stockholm }\end{array}$ & $\begin{array}{l}\text { Together with other six } \\
\text { ports in } \\
\text { Baltic Sea (EU funded } \\
\text { project } \\
\text { "LNG in Baltic Sea"a) } \\
\text { conducting } \\
\text { feasibility studies for } \\
\text { developing } \\
\text { LNG bunkering } \\
\text { infrastructure. }\end{array}$ & $\begin{array}{l}\text { The location of the second } \\
\text { LNG } \\
\text { facility is still under } \\
\text { decision, } \\
\text { while to be close to the } \\
\text { customer } \\
\text { (e.g., ferry lines) is the } \\
\text { key factor. }\end{array}$ & $\begin{array}{l}\text { Looking for the strategic } \\
\text { partners to develop the } \\
\text { second LNG bunkering } \\
\text { facility. }\end{array}$ & $\begin{array}{l}\text { PA invests and provides the } \\
\text { basic } \\
\text { port infrastructure, while } \\
\text { the onshore } \\
\text { facility will be invested } \\
\text { by private } \\
\text { actors. }\end{array}$ \\
\hline $\begin{array}{l}\text { Port of } \\
\text { Gothenburg }\end{array}$ & $\begin{array}{l}\text { Cooperating with strategic } \\
\text { partners to } \\
\text { conduct a feasibility } \\
\text { study on the } \\
\text { development of } \\
\text { bunkering terminal. }\end{array}$ & $\begin{array}{l}\text { The location has been } \\
\text { selected next } \\
\text { to the oil terminal by } \\
\text { considering } \\
\text { various factors, like } \\
\text { safety, } \\
\text { regulatory and economic } \\
\text { factors. }\end{array}$ & $\begin{array}{l}\text { 1. Establishing strategic } \\
\text { alliance with port of } \\
\text { Rotterdam on LNG } \\
\text { infrastructure. } \\
\text { 2. Together with Swedgas } \\
\text { and Vopak to develop } \\
\text { LNG bunkering facility. }\end{array}$ & $\begin{array}{l}\text { PA provides the basic port } \\
\text { infrastructure, } \\
\text { other facilities are } \\
\text { invested by Swedgas } \\
\text { and Vopak. PA together } \\
\text { with port of } \\
\text { Rotterdam got } 35 \text { million } \\
\text { euro EU } \\
\text { funding to support } \\
\text { investment. }\end{array}$ \\
\hline
\end{tabular}




\begin{tabular}{|c|c|c|c|c|}
\hline & $\begin{array}{c}\text { Establish a feasibility } \\
\text { study on LNG }\end{array}$ & Location selection policy & Strategic partnership & $\begin{array}{l}\text { Infrastructure investment } \\
\text { policy }\end{array}$ \\
\hline $\begin{array}{l}\text { Port of } \\
\text { Helsingborg }\end{array}$ & $\begin{array}{l}\text { Playing as a leading port } \\
\text { in EU } \\
\text { project "LNG in } \\
\text { Baltic Sea" with } \\
\text { other six ports to } \\
\text { conduct feasibility } \\
\text { studies for developing } \\
\text { LNG } \\
\text { bunkering } \\
\text { infrastructure. }\end{array}$ & $\begin{array}{l}\text { Conducting location study } \\
\text { with } \\
\text { consultant company. The } \\
\text { location } \\
\text { has been decided which } \\
\text { sits next } \\
\text { to the oil terminal mainly } \\
\text { considering safety } \\
\text { concern. }\end{array}$ & $\begin{array}{l}\text { Looking for the strategic } \\
\text { partners to develop the } \\
\text { LNG bunkering } \\
\text { infrastructure by } \\
\text { launching } \\
\text { public selection } \\
\text { procedure. }\end{array}$ & $\begin{array}{l}\text { The investment decision is } \\
\text { still under } \\
\text { discussion, while the port } \\
\text { possibly } \\
\text { invest with private actors } \\
\text { (e.g., PPP) for LNG } \\
\text { bunkering } \\
\text { facilities. }\end{array}$ \\
\hline
\end{tabular}

a EU funded project "LNG in Baltic Sea": There are seven partner ports joining this project: Ports of Aarhus, Helsingborg, Helsinki, Copenhagen-Malmo, Tallinn, Turku, and Stockholm. Port of Helsingborg as a leading port of this project aims to establish "stakeholder platform" among seven ports to share knowledge and skills on the development of LNG infrastructure. Source: own compilation

\section{References}

Acciaro M, Vanelslander T, Sys C, Ferrari C, Roumboutsos A, Giuliano G, Lam JSL, Kapros S (2013) Environmental sustainability in seaports: a framework for successful innovation. Paper presented at the 2013 IAME Conference, Marseille, France

Adams M, Quinonez P, Pallis AA, Wakeman TH (2010) Environmental issues in port competitiveness. Working Paper7, Centre for International Trade and Transportation

Åhman M (2006) Government policy and the development of electric vehicles in Japan. Energy Policy 34:433-443

Åstrand K, Neij L (2006) An assessment of governmental wind power programmes in Sweden - using a systems approach. Energy Policy 34:277-296

Baird AJ (1995) Privatization of trust ports in the United Kingdom: review and analysis of the first sales. Transp Policy 2:135-143

Baird AJ (2000) Port privatization: objectives, process and financing. Ports Harbours 45:14-19

Baltazar R, Brooks MR (2001) The governance of port devolution: a tale of two countries. Paper presented at the World Conference on Transport Research, Jun. 2001, Seoul

Bryan J, Munday M, Pickernell D, Roberts A (2006) Assessing the economic significance of port activity: evidence from ABP operations in industrial South Wales. Marit Policy Manag 33:371-386

Cahoon S, Pateman H, Chen SL (2013) Regional port authorities: leading players in innovation networks? J Transp Geogr 27:66-75

Chan CC, Chau KT (1997) An overview of power electronics in electric vehicles. IEEE Trans Ind Electron 44: 3-17

Chen SL, Cahoon S, Haugstetter H (2010) A regional port's role in its local innovation system: the regional development platform method. Paper presented at 2010 Annual conference of the International Association of Maritime Economists, July 2010, Lisbon, Portugal

Cheon SH, Deakin E (2010) Supply chain coordination for port sustainability. J Transp Res Board 2166(2): $10-19$

Chlomoudis CI, Karalis AV, Pallis AA (2003) Port reorganizations and the worlds of production theory. Eur J Transp Infrastruct Res 3:77-94

Comtois C, Slack B (2003) Innover l'autorité portuaire au 21ième siècle: un nouvel agenda de gouvernance. Cah Sci Transport 44:11-24

Cooke P, Uranga M, Etxebarria G (1998) Regional innovation systems: an evolutionary perspective. Environ Plan A 30:1563-1584

Cowan R, Hulten S (1996) Escaping lock-in: the case of the electric vehicle. Technol Forecast Soc Chang 53: 61-79

De Langen P (2004) Governance in seaport clusters. Marit Econ Logist 6:141-156 
De Langen PW (2007) Stakeholders, conflicting interests and governance in port clusters. In: Brooks MR, Cullinane K (eds) Devolution, port governance and port performance. Elsevier, Amsterdam, pp 457-477

De Langen PW, Chouly A (2004) Hinterland access regimes in seaports. Eur J Transp Infrastruct Res 4:361380

De Monie G (2004) Mission and role of port authorities after privatization. Paper presented at the ITMMA PPP Seminar, 2004, Antwerp

Denktas-Sakar G, Karatas-Cetin C (2012) Port sustainability and stakeholder management in supply chains: a framework on resource dependence theory. Asian J Shipp Logist 28:301-319

Doloreux D (2002) What should we know about regional systems of innovation? Technol Soc 24:243-263

Dooms M, Verbeke A (2007) Stakeholder management in ports: a conceptual framework integrating insights from research in strategy, corporate social responsibility and port management. Paper presented at the IAME 2007 Annual Conference, Athens

Eckstein H (1975) Case study and theory in political science. In: Greenstein FI, Polsby NW (eds) Strategies of inquiry. Addison-Wesley, Reading, pp 79-137

ESPO report (2013) Benchmarks of sustainability: process in environmental management system. Available at http://greenport.com/. Accessed 13 Sept 2013

Freeman C (1994) Critical survey - the economics of technical change. Camb J Econ 18:463-514

Goss R (1990) Economic policies and seaports-part 3: are port authorities necessary? Marit Policy Manag 17: $257-271$

Harmaakorpi V (2006) Regional development platform method (RDPM) as a tool for regional innovation policy. Eur Plan Stud 14:1085-1104

Hassink R (1993) Regional innovation policies compared. Urban Stud 30:1009-1024

Herriott RE, Firestone WA (1983) Multisite qualitative policy research: optimizing description and generalizability. Educ Res 12:14-19

Kim S, Dinwoodie J, Roe M (2013) The impact of sustainability practices on competitiveness in Busan: a mega container port in Northeast Asia. Presented at the 2013 IAME Conference, July, 2013, Marseille, France

Kostiainen J (2002) Urban economic development policy in the network society. Tekniikanakateemistenliitto, Tampere

Lam JSL, Van De Voorde E (2012) Green port strategy for sustainable growth and development. Presented at International Forum on Shipping, Ports and Airports, 2012, Hong Kong

Loiter JM, Norberg-Bohm V (1999) Technology policy and reviewable energy: public roles in the development of new energy technologies. Energy Policy 27:85-97

Mangan J, Lalwani C, Fynes B (2008) Port-centric logistics. Int J Logist Manag 19:29-41

Marlow PB, Paixão-Casaca AC (2003) Measuring lean port performance. Int J Transp Manag 1:189-202

Notteboom T (2007) Concession agreements as port governance tools. Res Transp Econ 17:437-455

Notteboom T, Rodrigue J-P (2005) Port regionalization: towards a new phase in port development. Marit Policy Manag 32:297-313

Notteboom T, Winkelmans W (2001a) Reassessing public sector involvement in European seaports. Int J Marit Econ 2:242-259

Notteboom T, Winkelmans W (2001b) Structural changes in logistics: how will port authorities face the challenge? Marit Policy Manag 28:71-89

Notteboom T, Winkelmans W (2002) Stakeholder relations management in ports: dealing with the interplay of forces among stakeholders in a changing competitive environment. Paper presented at the 2002 Annual conference of the International Association of Maritime Economists, Panama City

Pitt ME (2010) Natural gas versus diesel power for ships - a technical review, also considering economic aspects. DNV, Norway

Van Der Horst M, De Langen P (2007) Coordination in hinterland transport chains: a major challenge for the seaport community. Paper presented at the 2007 IAME Conference, Athens

Van Der Lugt L, De Langen PW (2007) Port authority strategy: beyond the landlord - a conceptual approach. Paper presented at the 2007 IAME Conference, Athens

Van Hooydonk E (2003) The regime of port authorities under European law (including an analysis of the port services directive). In: Van Hooydonk E (ed) European seaports law: EU law of ports and port services and the ports package. Maklu, Antwerpen, pp 79-187

Verhoeven P (2010) A review of port authority functions: towards a renaissance? Marit Policy Manag 37:247-270

Wang S, Notteboom T (2013) The perspectives and challenges of LNG as a ship fuel: conducting a systematic review and research syntheses. Paper presented at the IAME 2013 Conference, July, Marseille, France

Wiegmans BW, Geerlings H (2010) Sustainable port innovations: barriers and enablers for successful implementation. World Rev Intermodal Transp Res 3:230-250

Yin RK (2009) Case study research — design and methods, 4th edn. Sage Publications, Thousand Oaks 